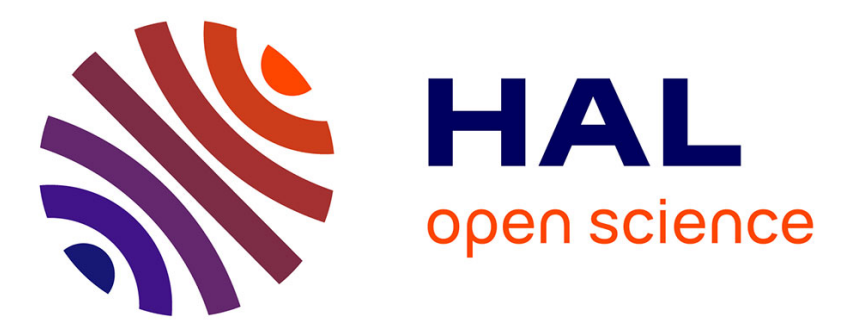

\title{
Synthesis and characterization of the most active copper ATRP catalyst based on tris $[(4$-dimethylaminopyridyl)methyl]amine
}

Thomas G. Ribelli, Marco Fantin, Jean-Claude Daran, Kyle F. Augustine, Rinaldo Poli, K. Matyjaszewski

\section{To cite this version:}

Thomas G. Ribelli, Marco Fantin, Jean-Claude Daran, Kyle F. Augustine, Rinaldo Poli, et al.. Synthesis and characterization of the most active copper ATRP catalyst based on tris[(4dimethylaminopyridyl)methyl]amine. Journal of the American Chemical Society, 2018, 140 (4), pp.1525-1534. 10.1021/jacs.7b12180 . hal-01954086

\section{HAL Id: hal-01954086 \\ https://hal.science/hal-01954086}

Submitted on 1 Mar 2021

HAL is a multi-disciplinary open access archive for the deposit and dissemination of scientific research documents, whether they are published or not. The documents may come from teaching and research institutions in France or abroad, or from public or private research centers.
L'archive ouverte pluridisciplinaire HAL, est destinée au dépôt et à la diffusion de documents scientifiques de niveau recherche, publiés ou non, émanant des établissements d'enseignement et de recherche français ou étrangers, des laboratoires publics ou privés. 


\title{
Synthesis and Characterization of the Most Active Copper ATRP Catalyst Based on Tris[(4- dimethylaminopyridyl)methyl]amine
}

\author{
Thomas G. Ribelli, ${ }^{\mathrm{a} \diamond}$ Marco Fantin, ${ }^{\mathrm{a} \diamond}$ Jean-Claude Daran, ${ }^{\mathrm{b}}$ Kyle F. Augustine, ${ }^{\mathrm{a}}$ \\ Rinaldo Poli ${ }^{\mathrm{b}, \mathrm{c}}$ and Krzysztof Matyjaszewski*a \\ aDepartment of Chemistry, Carnegie Mellon University, 4400 Fifth Avenue, Pittsburgh, PA \\ 15213, United States \\ ${ }^{b}$ CNRS, LCC (Laboratoire de Chimie de Coordination), Université de Toulouse, UPS, INPT, 205 \\ Route de Narbonne, BP 44099, F-31077, Toulouse Cedex 4, France \\ Institut Universitaire de France, 1, rue Descartes, 75231 Paris Cedex 05, France
}

\begin{abstract}
The synthesis and characterization of tris[(4-dimethylaminopyridyl)methyl]amine (TPMA ${ }^{\mathrm{NMe} 2}$ ) as a ligand for copper catalyzed atom transfer radical polymerization (ATRP) is reported. In solution, the [Cu'(TPMA $\left.{ }^{\mathrm{NMe} 2}\right) \mathrm{Br}$ ] complex shows fluxionality by variable temperature NMR, indicating rapid ligand exchange. In the solid-state, the $\left[\mathrm{Cu}^{\prime \prime}\left(\mathrm{TPMA}^{\mathrm{NMe} 2}\right) \mathrm{Br}\right][\mathrm{Br}]$ complex exhibits a slightly distorted trigonal bipyramidal geometry $(\tau=$ 0.89). The UV-Vis spectrum of [Cu" $\left.\left(\mathrm{TPMA}^{\mathrm{NMe}}\right) \mathrm{Br}\right]^{+}$salts is similar to those of other pyridinebased ATRP catalysts. Electrochemical studies of $\left[\mathrm{Cu}\left(\mathrm{TPMA}^{\mathrm{NMe} 2}\right)\right]^{2+}$ and $\left[\mathrm{Cu}\left(\mathrm{TPMA}^{\mathrm{NMe} 2}\right) \mathrm{Br}\right]^{+}$ showed highly negative redox potentials $\left(E_{1 / 2}=-302 \mathrm{mV}\right.$ and $-554 \mathrm{mV}$ vs. SCE, respectively), suggesting unprecedented ATRP catalytic activity. Cyclic voltammetry (CV) in the presence of methyl 2-bromopropionate (MBrP; acrylate mimic) was used to determine activation rate constant $k_{\mathrm{a}}=1.1 \times 10^{6} \mathrm{M}^{-1} \mathrm{~s}^{-1}$, confirming the extremely high catalyst reactivity. In the presence of the more active ethyl $\alpha$-bromoisobutyrate (EBiB; methacrylate mimic), total catalysis was observed and an activation rate constant $k_{\mathrm{a}}=7.2 \times 10^{6} \mathrm{M}^{-1} \mathrm{~s}^{-1}$ was calculated with values of $K_{\text {ATRP }}$ $\approx 1$. ATRP of methyl acrylate showed a well-controlled polymerization using as little as $10 \mathrm{ppm}$ of catalyst relative to monomer while side reactions such as $\mathrm{Cu}^{\prime}$ catalyzed radical termination (CRT) could be suppressed due to the low concentration of $L / C u^{\prime}$ at a steady-state.
\end{abstract}

\section{INTRODUCTION}

Atom transfer radical polymerization (ATRP) has gained widespread use due to its easy setup, tolerance to functional groups, mild conditions and wide range of applications. ${ }^{1-4}$ Since its inception in 1995, when stoichiometric amounts of air-sensitive Cu' relative to alkyl halide initiator were used, ${ }^{5}$ many advances have been made to improve the efficiency of this polymerization system. ${ }^{6}$ The development of new operating techniques such as initiators for continuous activator regeneration (ICAR) ATRP ${ }^{7-8}$, activators regenerated by electron transfer 
(ARGET) ATRP ${ }^{9-11}$, supplemental activators and reducing agents (SARA) ATRP ${ }^{12}$ as well as photoATRP ${ }^{13-17}$, eATRP ${ }^{18}$ and most recently mechanoATRP ${ }^{19-20}$ have allowed polymerizations to be conducted using ppm levels of catalyst relative to monomer.

As shown in Scheme 1, the control in ATRP is achieved via a reversible redox equilibrium between a $\mathrm{L} / \mathrm{Cu}^{\mathrm{I} / l l}$ couple where $\mathrm{L}$ signifies a multidentate nitrogen-based ligand. $\mathrm{L} / \mathrm{C} \mathrm{U}^{\prime}$ activates a (macro)alkyl halide chain end, resulting in the L/Cu"l-X deactivator and a carbon-based radical, ${ }^{21}$ which propagates by adding to monomer before being trapped by the $\mathrm{L} / \mathrm{Cu}$ " $\mathrm{X}$ deactivator, regenerating the $\mathrm{L} / \mathrm{Cu}$ ' species and the dormant polymer chain. ${ }^{4}$ To control the polymerization, ${ }^{22}$ this equilibrium ( $K_{\text {ATRP }}$ ) should lie on the dormant side to diminish the concentration of radicals and retain chain-end functionality (CEF). $K_{\text {ATRP }}$ can be expressed as the ratio of activation $\left(k_{\mathrm{a}}\right)$ to deactivation $\left(k_{\mathrm{d}}\right)$ rate constants and can be tuned over 8-orders of magnitude ${ }^{23}$ based on temperature, pressure, solvent, ${ }^{24-25}$ polymer chain-end, ${ }^{26}$ and choice of catalyst. ${ }^{23}$ In order to reach even lower catalyst loadings or to polymerize less active monomers such as vinyl acetate (VAc), ${ }^{27}$ higher values of $K_{\text {ATRP }}$ must be achieved.

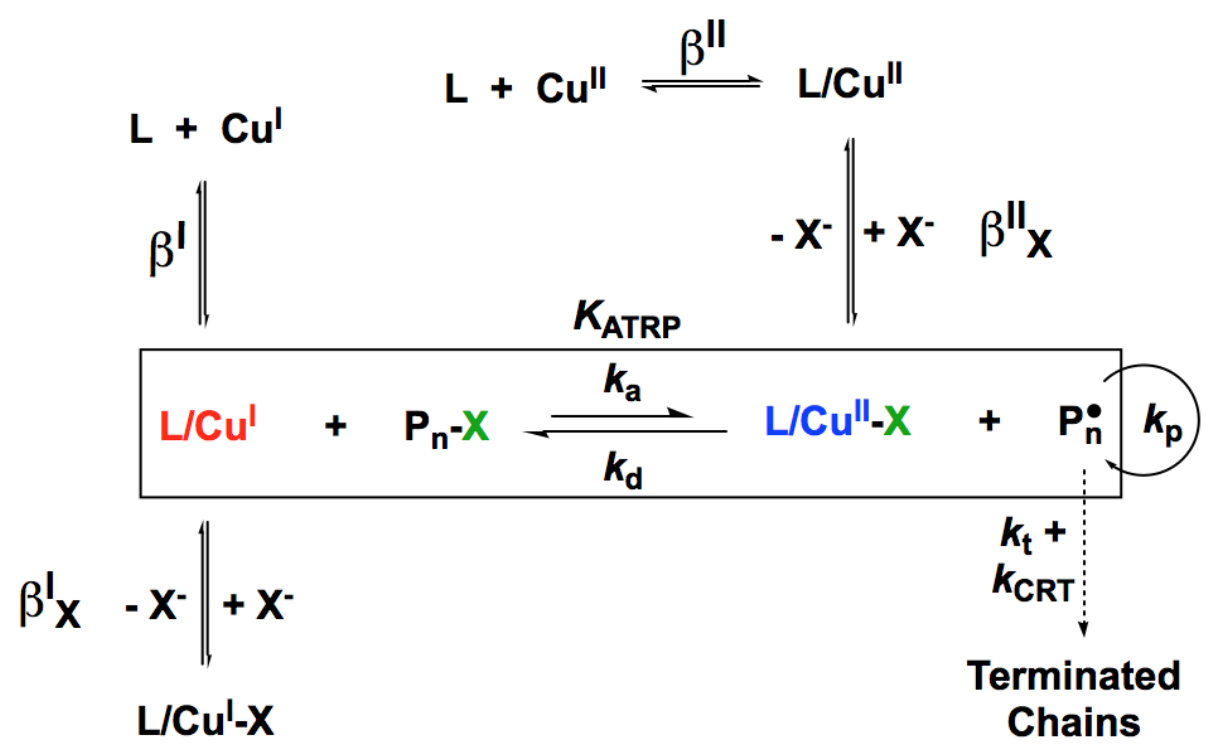

Scheme 1 Mechanism of ATRP (boxed) and equilibria involving association of ligand $\left(\beta^{m}\right)$ and halide $\left(\beta^{m}\right)$ to either the $\mathrm{Cu}^{\prime}(\mathrm{m}=\mathrm{I})$ or $\mathrm{Cu}{ }^{\prime \prime}(\mathrm{m}=\mathrm{II})$ ion.

One simple way to tune ATRP is by changing the coordination sphere of copper. Over the years, rational ligand design has allowed for the understanding of how the catalyst structure affects reactivity. The activity of the catalyst in ATRP correlates with ligand denticity, 
nature of the $\mathrm{N}$-donor atom and electron donating ability through the coordinating nitrogen atom(s). ${ }^{28}$ Indeed, a linear correlation between the redox potential $\left(E_{1 / 2}\right)$ and $\ln \left(K_{\text {ATRP }}\right)$ has been established where a more negative $E_{1 / 2}$ results in a larger value of $K_{\text {ATRP. }}{ }^{29}$ The activity of a catalyst can also be further assessed by comparing the stability constants (binding constants), $\beta$, of the $\mathrm{L} / \mathrm{Cu^{ \prime }}$ and $\mathrm{L} / \mathrm{Cu^{ \prime \prime }}$ complexes since $K_{\mathrm{ATRP}}$ scales with the $\beta^{\prime \prime} / \beta^{\prime}$ ratio, as shown in Scheme 1. While both $\beta^{\prime \prime}$ and $\beta^{\prime}$ should be large, $\beta^{\prime \prime}>\beta^{\prime}$ in order to provide a thermodynamic driving force for alkyl halide activation. ${ }^{29}$ Indeed, $\beta^{\prime}$ values are rather constant but $\beta^{\prime}$ values change significantly with the ligand structures. ${ }^{30}$

To date, the most active ATRP catalyst has used the ligand tris[((4-methoxy-2,5dimethyl)-2-pyridyl)methyl]amine (TPMA*3) which has three electron donating groups on each pyridine ring. ${ }^{31-32}$ This led to a catalyst that is 5 million times more active than the seminal catalytic system employing the 2,2'-bipyridine (bpy) ligand and 1000 times more active than the commonly used tris(pyridylmethyl)amine (TPMA) ligand (Scheme 2).

According to Hammett parameters, using the even more electron donating dimethyl amino $\left(-\mathrm{NMe}_{2}\right)$ group should further increase the catalyst activity as already observed for bpy

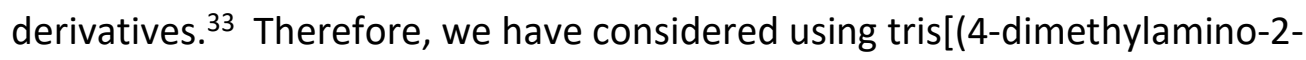
pyridyl)methyl]amine (TPMA ${ }^{\mathrm{NMe} 2}$ ) ligand as shown in Scheme S1. ${ }^{34-36}$ This ligand was previously reported by Karlin et al where the $\left[\mathrm{Cu}^{\prime}\left(\mathrm{TPMA}^{\mathrm{NMe} 2}\right)\right]^{+}$complex was used as an oxygen activation catalyst to mimic various copper containing enzymes ${ }^{37-38}$ such as amine oxdiases, ${ }^{39}$ multicopper oxidases $^{40}$ (MCOs) and tyrosinases ${ }^{41}$ as well as to study this complex's interactions with carbon monoxide. ${ }^{42}$ This new Cu-based ATRP catalyst with TPMA ${ }^{\mathrm{NMe} 2}$, in both relevant oxidation states, has been characterized in solution and the solid state and utilized in ATRP systems with low catalyst loadings (down to $10 \mathrm{ppm}$ ) and was shown to exhibit unprecedented reactivity with alkyl halides. 


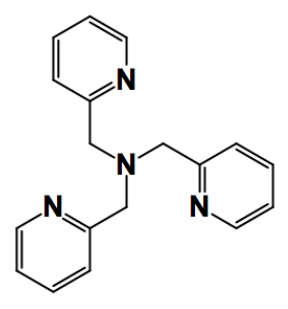

TPMA

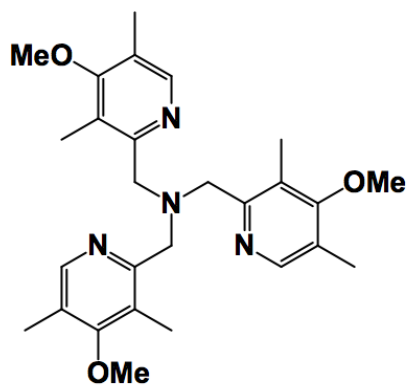

TPMA $^{* 3}$

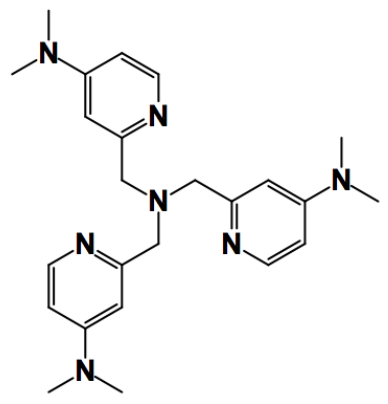

TPMA $^{\mathrm{NMe2}}$

Scheme 2 Structure of the ligands used in this study.

\section{RESULTS AND DISCUSSION}

TPMA $^{\mathrm{NMe} 2}$ was prepared by a procedure slightly modified from that used by Karlin et al ${ }^{34}$ (Scheme S1). The synthesis of 2-hydroxymethyl-4-dimethylaminopyridine (2; Scheme S1) was conducted as previously published by Comba et al. ${ }^{35}$ The synthesis of 2-phthalimidomethyl-4chloropyridine (5; Scheme S1) was conducted as previously published by our group. ${ }^{31} 2$ Aminomethyl-4-dimethylpyridine (6; Scheme S1) was synthesized directly from a basic workup of 2-phthalimidomethyl-4-dimethylaminopyridine. It should be noted that it is very important to use chemical resistant O-Ring (ACE glass \# 7855-813) for reactions using high pressure tubes. The ligand has been characterized by ${ }^{1} \mathrm{H} /{ }^{13} \mathrm{C}$ NMR and ESI-MS which confirmed the predicted structure.

\section{Variable Temperature NMR of Cu' complexes}

It has been previously shown that L/Cu' complexes with multidentate pyridine-based ligands can undergo fast ligand exchange in the presence of excess ligand relative to $\mathrm{Cu}^{\prime} .^{43}$ The solution prepared by addition of TPMA ${ }^{\mathrm{NMe} 2}$ to $\mathrm{CuBr}$ was studied by variable temperature NMR, as shown in Figure 1. 


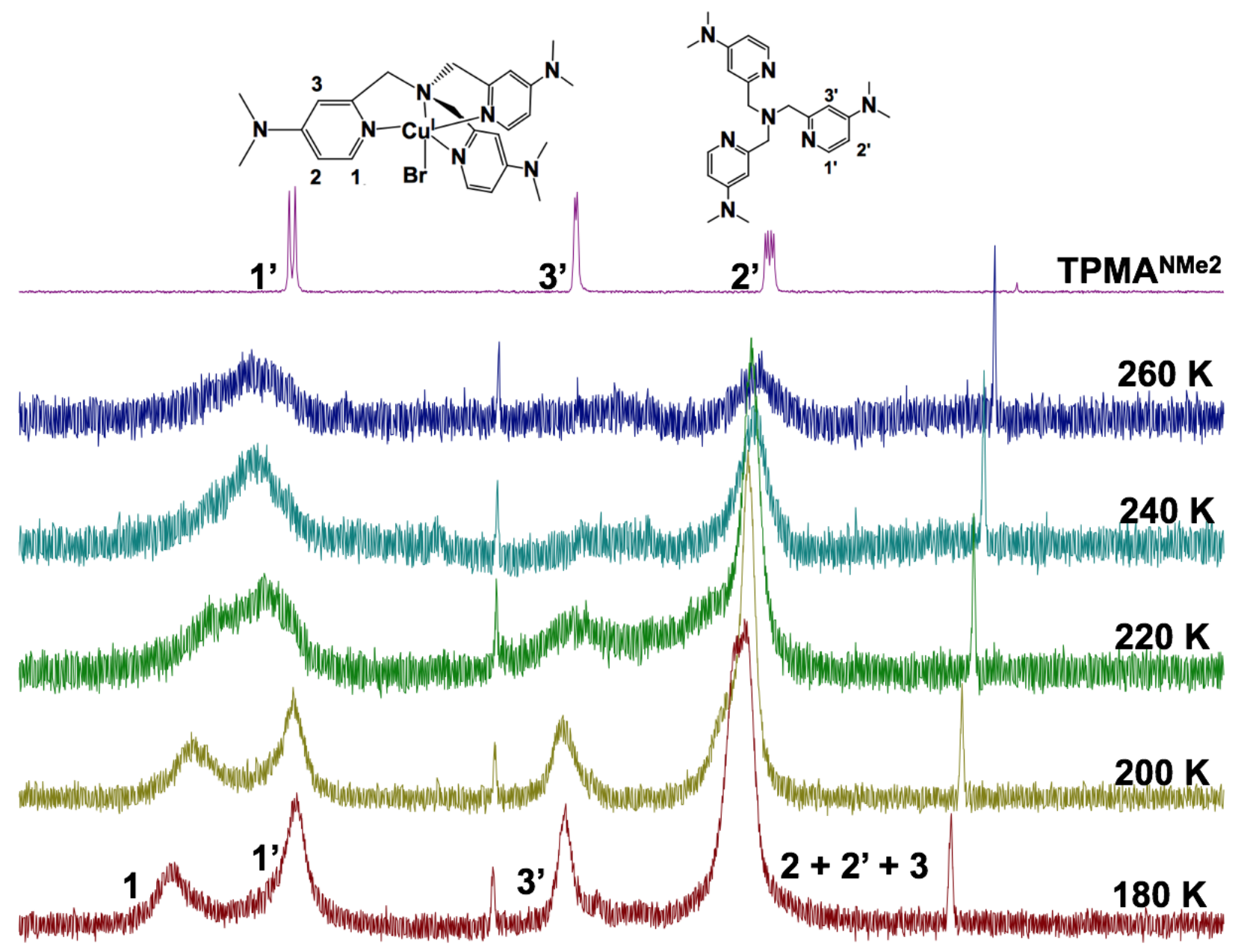

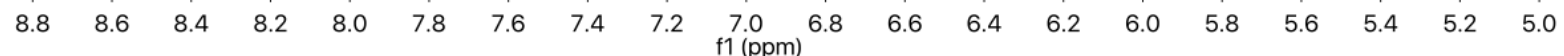

Figure 1 Variable temperature ${ }^{1} \mathrm{H}$ NMR of the aromatic region of the free TPMA ${ }^{\mathrm{NMe} 2}$ ligand and its $\mathrm{CuBr}$ complex at the molar ratio $[\mathrm{CuBr}]_{0}:\left[\mathrm{TPMA}^{\mathrm{NMe} 2}\right]_{0}=1: 3$ in $d_{6}$-acetone.

Upon reacting equimolar amounts of $\mathrm{TPMA}^{\mathrm{NMe} 2}$ and $\mathrm{CuBr}$ in $d_{6}$-acetone, the reaction initially turned to a pale-yellow color, common for $\mathrm{Cu}^{\prime}$ complexes coordinated by pyridinic ligands. However, upon stirring, the reaction mixture turned green along with a dark precipitate indicative that the $\left[\mathrm{Cu}^{\prime}\left(\mathrm{TPMA}^{\mathrm{NMe}}\right) \mathrm{Br}\right.$ ] complex underwent disproportionation to $\left[\mathrm{Cu}^{\prime \prime}\left(\mathrm{TPMA}^{\mathrm{NMe} 2}\right) \mathrm{Br}\right][\mathrm{Br}]$ and $\mathrm{Cu}^{0}+\mathrm{TPMA}^{\mathrm{NMe2}}$. Typically, unsubstituted TPMA shows little to no disproportionation. The position of the disproportionation equilibrium, $K_{\mathrm{Disp}, \mathrm{LCu}}$, depends on the relative stability of LCu" compared LCu'. Since the TPMA ${ }^{\mathrm{NMe} 2}$ stabilizes $\mathrm{Cu}^{\text {Il }}$ much more than TPMA, disproportionation is not unexpected. This is especially true in a disproportionating 
solvent such as acetone which is polar and coordinates weakly to $\mathrm{Cu}^{\prime}{ }^{29}$ To suppress disproportionation and reform the [Cu'(TPMA $\left.\left.{ }^{\mathrm{NMe} 2}\right) \mathrm{Br}\right]$ complex, 2 additional equivalents of $\mathrm{TPMA}^{\mathrm{NMe} 2}$ were added. ${ }^{44}$ Indeed, upon further stirring for 30 minutes, the reaction regained its yellow color and the $\mathrm{Cu}^{0}$ particles were no longer visible.

The ${ }^{1} \mathrm{H}$ NMR spectrum shows significant broadening of the aromatic peaks upon complexation, which has been previously been shown for other $\mathrm{Cu}^{\prime}$ complexes. ${ }^{45-47}$ This broadening indicates a fast exchange between free and coordinated ligand. Upon decreasing the temperature to $240 \mathrm{~K}$, the peaks attributed to coordinated and uncoordinated ligand began to resolve due to the slower rate of exchange. At $180 \mathrm{~K}$, two distinct peaks were observed at 8.05 and 8.5 ppm, attributed to free and coordinated ligand, respectively. ${ }^{43,48-51}$ The peaks became narrower at lower temperature but were broader than those of previously published TPMA-based Cu' complexes at $180 \mathrm{~K}$. This could be due to the presence of small amounts of paramagnetic $\mathrm{Cu}^{\prime \prime}$ formed from disproportionation and plausible self-exchange between the $\mathrm{Cu}^{\prime \prime}$ and $\mathrm{Cu}^{\prime}$ complexes. This cannot be avoided due to the disproportionating nature of acetone and the highly reactive $\left[\mathrm{Cu}^{\prime}\left(\mathrm{TPMA}^{\mathrm{NMe} 2}\right)\right]^{+}$complex. Although the variable temperature NMR spectra indicate a significant amount of ligand exchange, the total amount of uncoordinated $\mathrm{Cu}$ is extremely low due to the large stability constants, $\beta^{\prime}$, as has been previously observed for substituted TPMA ligands. ${ }^{43}$

\section{Structural Studies of $\mathrm{Cu}$ " Deactivator Complex The $\left[\mathrm{Cu}^{\prime \prime}\left(\mathrm{TPMA}^{\mathrm{NM} 2}\right) \mathrm{Br}\right]^{+}$complex was} synthesized and crystallized as reported in the Supporting Information. The resulting molecular structure is presented in Figure $\mathbf{2}$ with selected bond distances and angles summarized in Table 1.

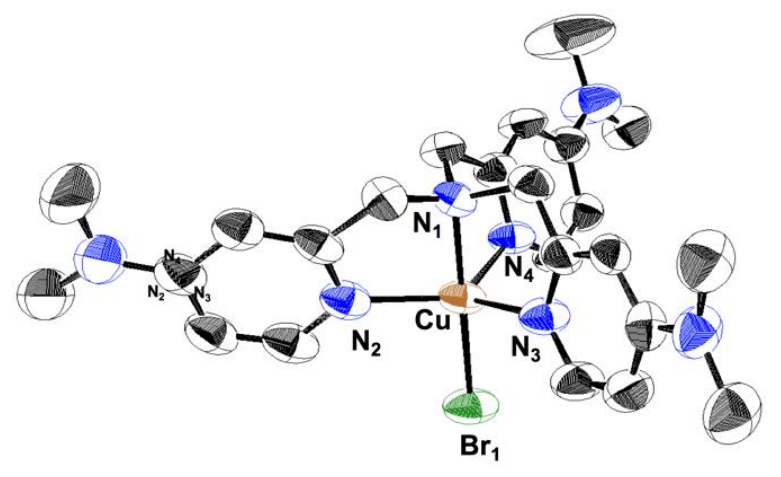


Figure 2 Molecular structure of [Cu"(TPMA $\left.{ }^{\mathrm{NMe}}\right) \mathrm{Br}$ ] $[\mathrm{Br}$ ] shown (left) with $50 \%$ probability displacement ellipsoids. $\mathrm{H}$ atoms, counter $\mathrm{Br}^{-}$anion and solvent molecules have been omitted for clarity.

The $\left[\mathrm{Cu}^{\prime \prime}\left(\mathrm{TPMA}^{\mathrm{NMe} 2}\right) \mathrm{Br}\right]^{+}$cation is in a slightly distorted trigonal bipyramidal geometry, indicated by a structural parameter $\tau=0.89(\tau=1.00$ for trigonal bipyramidal). Coordination of the tetradentate ligand occurs through three substituted pyridinic nitrogen atoms in the equatorial plane $\left(\mathrm{N}_{\mathrm{eq}}\right)$ and a central anchoring aliphatic nitrogen in the axial plane $\left(\mathrm{N}_{\mathrm{ax}}\right)$. The $\mathrm{Nax}^{-}$ $\mathrm{Cu}-\mathrm{N}_{\text {eq }}$ bond angles are all slightly smaller than $90^{\circ}$ which is consistent with a previously reported cupric aqua adduct, ${ }^{36}\left[\mathrm{Cu}^{\prime \prime}\left(\mathrm{TPMA}^{\mathrm{NMe2}}\right)\left(\mathrm{H}_{2} \mathrm{O}\right)\right]^{2+}$. The similar $\mathrm{N}_{\mathrm{ax}}-\mathrm{Cu}-\mathrm{N}_{\text {eq }}$ angles between the two complexes, although with differently sized axial ligands $\left(\mathrm{Br}^{-}\right.$vs. $\left.\mathrm{H}_{2} \mathrm{O}\right)$, suggests these deviations from $90^{\circ}$ are most likely due to the natural bite of the ligand as opposed to steric repulsion from the axial ligand. The previously reported ${ }^{42}$ cuprous carbonyl adduct, $\left[\mathrm{Cu}^{\prime}\left(\mathrm{TPMA}^{\mathrm{NMe} 2}\right)(\mathrm{CO})\right]^{+}$, showed a Cu'-Nax bond distance of $2.446 \AA$ which is significantly elongated compared to the $\mathrm{Cu}^{\prime \prime}-\mathrm{N}_{\mathrm{ax}}$ bond distance of $2.05 \AA$ presented in this study. Although the two complexes cannot be directly compared due to the difference in axial ligand, $\mathrm{Cu}-\mathrm{N}_{\mathrm{ax}}$ bond elongation upon reduction of $\mathrm{Cu}^{\prime \prime}$ to $\mathrm{Cu}^{\prime}$ has been observed in other TPMA-based complexes. ${ }^{52}$ This is attributed to $\mathrm{Cu}^{\text {II }}$ preferring a 5-coordinate environment while the reduced $\mathrm{Cu}^{\prime}$ ion prefers 4-coordinate geometries. ${ }^{53}$ Thus, the $\mathrm{Cu}^{\prime}-\mathrm{N}_{\mathrm{ax}}$ bond is elongated to a nonbonding distance forming a distorted tetrahedral geometry. Furthermore, as shown in Figure S5, the crystal structure is stabilized by $\pi-\pi$ stacking interactions between substituted pyridine rings as well as weak $\mathrm{C}-\mathrm{H}---\mathrm{Br}(2.84 \AA)$ interactions.

Table 1 Selected Bond Distances and Angles of Relevance for L/Cu"-Br Deactivator Species ${ }^{\mathrm{a}}$

\begin{tabular}{|c|c|c|c|}
\hline & {$\left[\mathrm{Cu}{ }^{\prime \prime}(\mathrm{TPMA}) \mathrm{Br}\right][\mathrm{Br}]^{\mathrm{b}}$} & {$\left[\mathrm{Cu}^{\prime \prime}\left(\mathrm{TPMA}^{* 3}\right) \mathrm{Br}\right][\mathrm{Br}]^{\mathrm{c}}$} & {$\left[\mathrm{Cu}{ }^{\prime \prime}\left(\mathrm{TPMA}^{\mathrm{NMe}}\right) \mathrm{Br}\right][\mathrm{Br}]^{\mathrm{d}}$} \\
\hline $\mathrm{Cu}-\mathrm{N} 1_{\mathrm{ax}}$ & $2.040(3)$ & $2.028(3)$ & $2.047(3)$ \\
\hline $\mathrm{Cu}-\mathrm{N} 2_{\mathrm{eq}}$ & $2.073(15)$ & $2.059(3)$ & $2.051(2)$ \\
\hline $\mathrm{Cu}-\mathrm{N3}_{\mathrm{eq}}$ & $2.073(15)$ & $2.149(3)$ & $2.108(3)$ \\
\hline $\mathrm{Cu}-\mathrm{N} 4_{\mathrm{eq}}$ & $2.073(15)$ & $2.044(3)$ & $2.046(3)$ \\
\hline $\mathrm{Cu}-\mathrm{Br}_{1}$ & $2.384(6)$ & $2.3740(5)$ & $2.3898(6)$ \\
\hline $\mathrm{N}_{1}-\mathrm{Cu}-\mathrm{N}_{2}$ & $80.86(5)$ & $81.07(12)$ & $80.59(10)$ \\
\hline $\mathrm{N}_{1}-\mathrm{Cu}-\mathrm{N}_{3}$ & $80.86(5)$ & $82.81(12)$ & $80.60(10)$ \\
\hline
\end{tabular}




$\begin{array}{cccc}\mathrm{N}_{1}-\mathrm{Cu}-\mathrm{N}_{4} & 80.86(5) & 79.82(11) & 81.42(10) \\ \mathrm{N}_{2}-\mathrm{Cu}-\mathrm{N}_{3} & 117.53(3) & 132.39(12) & 126.78(10) \\ \mathrm{N}_{2}-\mathrm{Cu}-\mathrm{N}_{4} & 117.53(3) & 115.63(12) & 116.34(10) \\ \mathrm{N}_{3}-\mathrm{Cu}-\mathrm{N}_{4} & 117.53(3) & 104.99(12) & 109.40(10) \\ \mathrm{N}_{1}-\mathrm{Cu}-\mathrm{Br}_{1} & 180.00(5) & 178.33(9) & 179.89(9) \\ \mathrm{N}_{2}-\mathrm{Cu}-\mathrm{Br}_{1} & 99.14(5) & 100.99(8) & 98.59(8) \\ \mathrm{N}_{3}-\mathrm{Cu}-\mathrm{Br}_{1} & 99.14(5) & 98.35(8) & 99.49(7) \\ \mathrm{N}_{4}-\mathrm{Cu}-\mathrm{Br}_{1} & 99.14(5) & 97.27(8) & 99.32(7) \\ \tau^{\mathrm{e}} & 1.0 & 0.77 & 0.89\end{array}$

aBond lengths are given in angstroms $(\AA)$ and angles in degrees $\left({ }^{\circ}\right)$. ${ }^{b}$ From Ref $51 .{ }^{c}$ From Ref 42. ${ }^{\mathrm{d}}$ This work. ${ }^{\mathrm{e}} \tau$ parameter is calculated as $\tau=\left(\phi_{1}-\phi_{2}\right) / 60$, where $\phi_{1}$ and $\phi_{2}$ are the largest $\left(\mathrm{N}_{1}-\right.$ $\left.\mathrm{Cu}-\mathrm{Br}_{1}\right)$ and second largest $\left(\mathrm{N}_{2}-\mathrm{Cu}-\mathrm{N}_{3}\right)$ bond angles, $\tau=1$ (trigonal bipyramidal geometry), and $\tau$ $=0$ (square pyramidal geometry).

Solution Studies of $\mathrm{Cu}^{\prime \prime}$ Complexes The UV-Vis-NIR spectra were obtained using $\mathrm{CuBr}_{2}$ to form $\left[\mathrm{Cu}^{\prime \prime}\left(\mathrm{TPMA}^{\mathrm{NMe} 2}\right) \mathrm{Br}\right]^{+}$and also $\mathrm{Cu}(\mathrm{OTf})_{2}$ to form $\left[\mathrm{Cu}^{\prime \prime}\left(\mathrm{TPMA}^{\mathrm{NMe} 2}\right)(\mathrm{MeCN})\right]^{2+}$, since the OTf ${ }^{-}$anion coordinates very weakly to the $\mathrm{Cu}^{\prime \prime}$ center in solution. As shown in Figure $\mathbf{3 A}$, two $d \rightarrow d$ transitions are observed in the NIR and visible region at 1038 and $776 \mathrm{~nm}$ for the $\left[\mathrm{Cu}^{\prime \prime}\left(\mathrm{TPMA}^{\mathrm{NMe} 2}\right) \mathrm{Br}\right]^{+}$and 980 and $725 \mathrm{~nm}$ for the $\left[\mathrm{Cu}^{\prime \prime}\left(\mathrm{TPMA}^{\mathrm{NMe} 2}\right)(\mathrm{MeCN})\right]^{2+}$ complex, respectively. These two transitions are typical of $d^{9} \mathrm{Cu}^{\prime \prime}$ possessing trigonal bipyramidal geometry and are attributed to $\mathrm{d}_{\mathrm{xz}} \approx \mathrm{d}_{\mathrm{yz}} \rightarrow \mathrm{d}_{\mathrm{zz} 2}$ and to $\mathrm{d}_{\mathrm{x} 2-\mathrm{y} 2} \approx \mathrm{d}_{\mathrm{xy}} \rightarrow \mathrm{d}_{\mathrm{z2} \text {. }}{ }^{54-55}$ A ligand to metal charge transfer (LMCT) band is apparent in both complexes, centered around 425 and $395 \mathrm{~nm}$ for $\left[\mathrm{Cu}^{\prime \prime}\left(\mathrm{TPMA}^{\mathrm{NMe} 2}\right) \mathrm{Br}\right]^{+}$and $\left[\mathrm{Cu}\left(\mathrm{TPMA}^{\mathrm{NMe} 2}\right)(\mathrm{MeCN})\right]^{2+}$, respectively. The absorption spectra of these two complexes are consistent with previously published results for many ATRP deactivator complexes presenting trigonal bipyramidal geometry. ${ }^{43,56} \mathrm{~A}$ sample of $\left[\mathrm{Cu}^{\prime \prime}\left(\mathrm{TPMA}^{\mathrm{NMe}}\right) \mathrm{Br}\right][\mathrm{Br}]$ crystals was also investigated, after dissolution into a dichloromethane/toluene mixture, by EPR spectroscopy at $120 \mathrm{~K}$ (Figure 3B), revealing a pattern and g/A parameters rather close to those of the related [Cu"(TPMA)Br] $]^{+}$complex. A rather uninformative cubit tensor at $\mathrm{g}=2.123$ and a linewidth of ca. $110 \mathrm{G}$, without observable copper hyperfine coupling was observed, on the other hand, under the same conditions in a $\mathrm{MeCN} /$ toluene mixture, as well as in pure $\mathrm{MeCN}$ or pure dichloromethane (see Supporting Information Figure S4). 

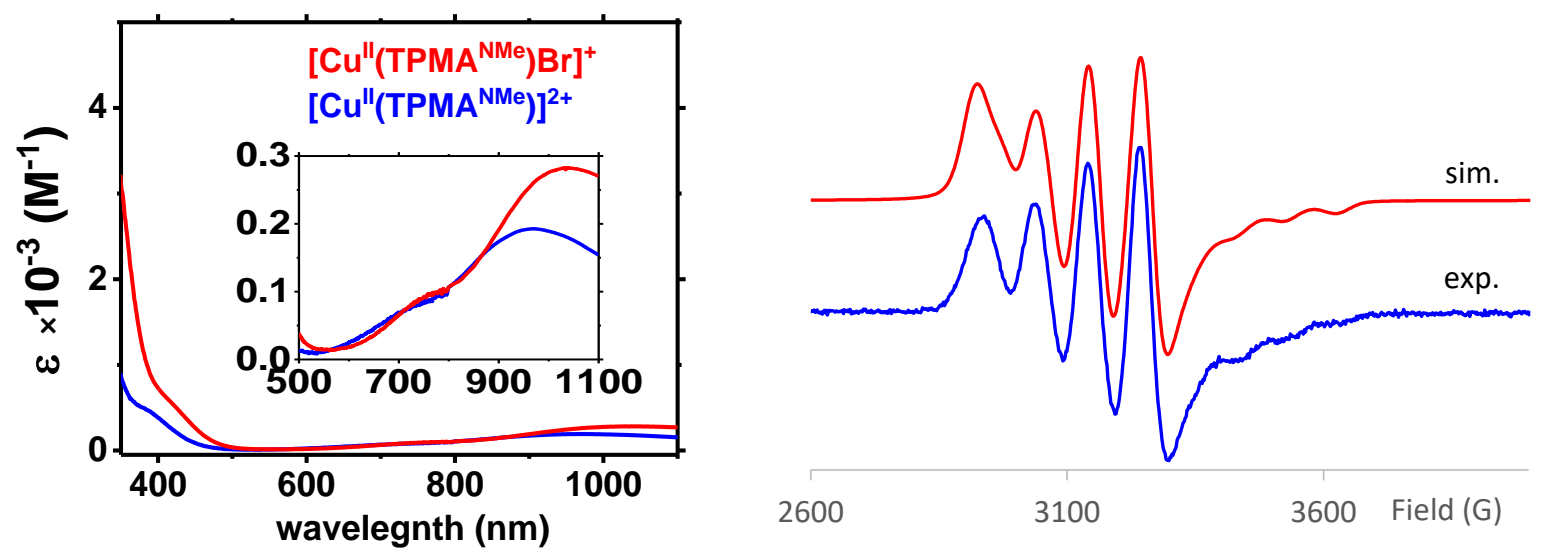

Figure $3 \mathrm{~A}$ : Absorption spectra of the [Cu" $\left.\left(\mathrm{TPMA}^{\mathrm{NMe} 2}\right) \mathrm{Br}\right]^{+}$deactivator complex (red) and $\left[\mathrm{Cu}^{\prime \prime}\left(\mathrm{TPMA}^{\mathrm{NMe} 2}\right)(\mathrm{MeCN})\right]^{2+}$ complex (blue) in MeCN. $\left[\mathrm{CuX}_{2}\right]_{0}=1 \mathrm{mM}\left(\mathrm{X}=\mathrm{Br}^{-}\right.$or OTf $\mathrm{OT}^{-}$. Add MeCN to complex name $B$ : Experimental (blue) and simulated (red) EPR spectrum of the [Cu" (TPMA $\left.\left.{ }^{\mathrm{NMe} 2}\right) \mathrm{Br}\right]^{+}$deactivator complex in a $1: 1 \mathrm{CH}_{2} \mathrm{Cl}_{2} /$ toluene mixture at $120 \mathrm{~K}\left(\mathrm{~g}_{1}=2.198, \mathrm{~A}_{1}\right.$ $=336.5 \mathrm{MHz} ; \mathrm{g}_{2}=2.173, \mathrm{~A}_{2}=255.3 \mathrm{MHz} ; \mathrm{g}_{3}=260.1, \mathrm{~A}_{3}=260.1 \mathrm{MHz}$ ).

Thermodynamic Parameters As noted above, one method to determine catalyst activity in ATRP is by measuring the stability constants, $\beta^{\prime}$ and $\beta^{\prime \prime}$, for the $\mathrm{L} / \mathrm{C} \mathrm{U}^{\prime}$ and $\mathrm{L} / \mathrm{C} \mathrm{u}^{\prime \prime}$ complexes. ${ }^{43}$ The redox potential of the $[\mathrm{Cu}(\mathrm{L})]^{2+}$ complex gives the $\beta^{\prime \prime} / \beta^{\prime}$ ratio as shown in Eq 1, where $E_{\mathrm{Cu}^{2+} / \mathrm{Cu}^{+}}^{\circ}$ and $E_{\mathrm{LCu}^{\mathrm{II}} / \mathrm{LCu}^{\mathrm{I}}}^{\circ}$ represent the standard redox potential of solvated $\mathrm{Cu}$ and the ligated Cu species, respectively. ${ }^{57}$ Furthermore, according to Eq 2, it is also possible to obtain the ratio $\beta_{\mathrm{X}, \mathrm{app}}^{\mathrm{II}} / \beta_{\mathrm{X}, \mathrm{app}}^{\mathrm{I}}$ electrochemically, where $\beta_{\mathrm{X}, \text { app }}^{\mathrm{II}}$ and $\beta_{\mathrm{X}, \text { app }}^{\mathrm{I}}$ are the apparent equilibrium constants of halide association to ligated copper, $\mathrm{L} / \mathrm{Cu}^{\prime \prime}-\mathrm{X}$ or $\mathrm{L} / \mathrm{Cu} \mathrm{I}^{\prime}-\mathrm{X}$, respectively. ${ }^{43}$ For efficient deactivation, $\beta_{X}^{I I}$ values must be high. Values of $\beta_{X}^{I}$ should be low, since the $\left[C u^{\prime}(L) B r\right]$ is an inefficient activator in ATRP. 58

$\ln \frac{\beta^{\mathrm{I}}}{\beta^{\mathrm{II}}}=\frac{F}{R T}\left(E_{\mathrm{Cu}^{2+} / \mathrm{Cu}^{+}}^{\mathrm{o}}-E_{\mathrm{LCu}^{\mathrm{II}} / \mathrm{LCu}}^{\mathrm{I}}\right)$

$\ln \frac{\beta_{\mathrm{X}}^{\mathrm{II}}}{\beta_{\mathrm{X}}^{\mathrm{I}}}=\frac{F}{R T}\left(E_{\mathrm{LCu}^{\mathrm{II}} / \mathrm{LCu}^{\mathrm{I}}}^{\mathrm{o}}-E_{\mathrm{LCu}^{\mathrm{II}}-\mathrm{X} / \mathrm{LCu}^{\mathrm{I}}-\mathrm{X}}^{\mathrm{o}}\right)$ 
As shown in Figure 4, both the $\left[\mathrm{Cu}\left(\mathrm{TPMA}^{\mathrm{NMe} 2}\right)(\mathrm{MeCN})\right]^{2+}$ and $\left[\mathrm{Cu}\left(\mathrm{TPMA}^{\mathrm{NMe} 2}\right) \mathrm{Br}\right]^{+}$ complexes exhibit a reversible redox wave at $E_{1 / 2}=-302 \mathrm{mV}$ and $-554 \mathrm{mV}$ vs. SCE, respectively, representing the most reducing ATRP catalysts to date. Separation between the anodic and cathodic peaks is ca. $60 \mathrm{mV}$ at a scan rate of $0.2 \mathrm{~V} \mathrm{~s}^{-1}$, indicating good reversibility. Increasing the scan rate results in the expected increase in current; peak separation also increases, revealing a quasi-reversible nature of the electron transfer. This shows that the TPMA ${ }^{\mathrm{NM} 2}$ ligand is able to sufficiently stabilize the electrochemically generated $\mathrm{Cu}^{\prime}$, and indicates that these complexes have small rearrangement energies between the $\mathrm{Cu}^{1 / 11}$ oxidation states. Using Eq 1 , the $\beta^{\prime \prime} / \beta^{\prime}$ ratio was calculated as $1.1 \times 10^{23}$ which is 1500 times larger than the previously reported value for the tris(2-dimethylaminoethyl)amine (Me 6 TREN) complex in MeCN. ${ }^{57}$ This large increase may be either due to a more stabilized $\mathrm{Cu}^{\prime \prime}$ or a destabilized $\mathrm{Cu}^{\prime}$. However, it was previously shown ${ }^{43}$ that stability constants for $\mathrm{Cu}^{\prime}$ were similar using variously substituted pyridine-based ligands in DMF. ${ }^{30}$

Upon introduction of coordinating bromide anions, the complex $\left[\mathrm{Cu}\left(\mathrm{TPMA}^{\mathrm{NMe} 2}\right) \mathrm{Br}\right]^{+}$is formed, and the redox potential shifts by $-252 \mathrm{mV}$ to give $E_{1 / 2}=-554 \mathrm{mV}$ vs. SCE. $K_{\text {ATRP }}$ increases roughly one order of magnitude for every $59 \mathrm{mV}$ shift of redox potential, indicating $K_{\text {ATRP }}$ should be approximately 140,000 times greater relative to the unsubstituted TPMA-based catalyst, which has $E_{1 / 2}=-240 \mathrm{mV}$ vs. $\mathrm{SCE},{ }^{46}$ and $>10^{9}$ times greater than the original bpy catalyst, which has $E_{1 / 2}=+30 \mathrm{mV}$ vs. SCE. ${ }^{59}$ Furthermore, using Eq. 2, the $\beta_{\mathrm{X}, \text { app }}^{\mathrm{II}} / \beta_{\mathrm{X}, \text { app }}^{\mathrm{I}}$ ratio was calculated to be $1.8 \times 10^{4}$, similar to that of other TPMA-based ligands in MeCN. ${ }^{43}$

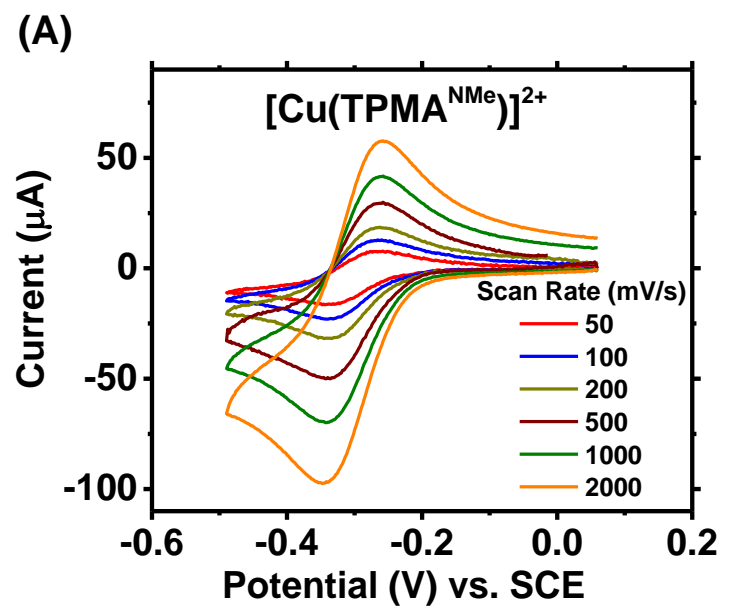

(B)

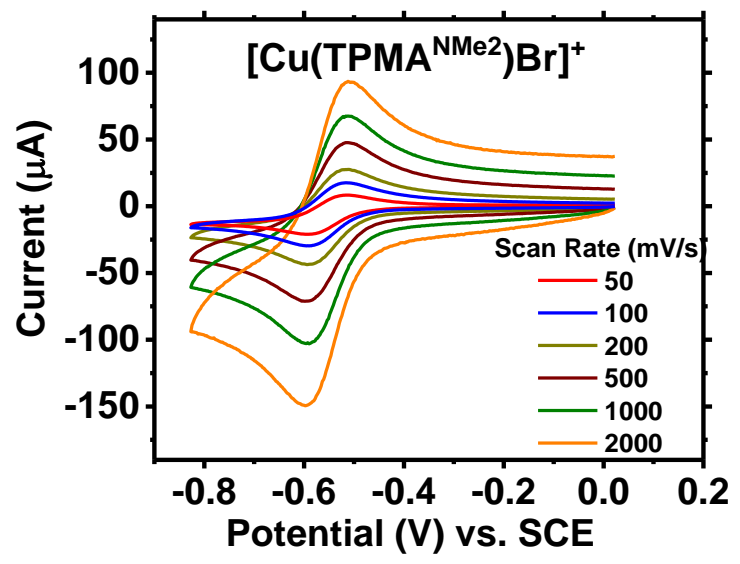


Figure 4 Cyclic voltammograms of (A) $1 \mathrm{mM}\left[\mathrm{Cu}\left(\mathrm{TPMA}^{\mathrm{NMe} 2}\right)(\mathrm{MeCN})\right]^{2+}$ and (B) $1 \mathrm{mM}$ $\left[\mathrm{Cu}\left(\mathrm{TPMA}^{\mathrm{NMe} 2}\right) \mathrm{Br}\right]^{2+}+20 \mathrm{mM} \mathrm{Et}_{4} \mathrm{NBr}$ in dry $\mathrm{MeCN}$ at different scan rates using $\mathrm{Et}_{4} \mathrm{NBF}_{4}$ as a supporting electrolyte and glassy carbon working electrode; $\left[\mathrm{L} / \mathrm{Cu}{ }^{\prime \prime}\right]_{0}=1 \mathrm{mM}$.

$$
\begin{aligned}
& K_{\mathrm{disp}, \mathrm{LCu}}=\frac{\left[\mathrm{LCu}^{\mathrm{II}}\right]_{\mathrm{eq}}[\mathrm{L}]_{\mathrm{eq}}}{\left[\mathrm{LCu}^{\mathrm{I}}\right]_{\mathrm{eq}}^{2}} \\
& \frac{\beta^{\mathrm{II}}}{\left(\beta^{\mathrm{I}}\right)^{2}}=\frac{K_{\mathrm{disp}, \mathrm{LCu}}}{K_{\mathrm{disp}, \mathrm{Cu}}}
\end{aligned}
$$

Since cyclic voltammetry can only provide the $\beta^{\prime \prime} / \beta^{\prime}$ ratio, further analysis was carried out to estimate the individual $\beta$ values. We previously reported ${ }^{43}$ on the disproportionation equilibrium allowing for the calculation of $\beta^{\prime \prime} /\left(\beta^{\prime}\right)^{2}$, as shown in Eq's $\mathbf{3} \boldsymbol{\&}$ 4, where $K_{\text {disp, LCu }}$ and $K_{\text {disp,Cu }}$ are the equilibrium constants of disproportionation for ligated and solvated copper, respectively. ${ }^{43}$ The determination of the disproportionation equilibrium, when coupled with electrochemical measurements, allows for the calculation of individual stability constants.

Analysis of $K_{\text {disp, LCu }}$ is difficult in MeCN due to the highly comproportionating nature of this solvent, i.e. very small values of $K_{\text {disp, }}$. In fact, values of $K_{\text {disp,cu }}$ for the solvated Cu' complex in acetonitrile have previously been estimated on the order of $10^{-21} .60$ Therefore, it was only possible to estimate a limit of $K_{\text {disp, } \mathrm{LC} u}<1.0 \times 10^{-4}$. Nonetheless, using this value the lower limits of $\beta^{\prime \prime}$ and $\beta^{\prime}$ as $3.5 \times 10^{29}$ and $1.9 \times 10^{6}$ were estimated, respectively. These values, although likely underestimated due to uncertainty of $K_{\text {disp,LCu, }}$ are in good agreement with previously reported values for other ATRP catalysts. ${ }^{43,57}$ All thermodynamic parameters obtained in this study, as well as for TPMA and TPMA*3-based complexes, are summarized in Table 2 . It should be noted that values of $\beta^{\prime}$ are significantly limited by unattainable values of $K_{\text {disp,LCu }}$ in MeCN.

Table 2 Thermodynamic Properties of the $[\mathrm{Cu}(\mathrm{L})(\mathrm{MeCN})]^{2+}$ and $[\mathrm{Cu}(\mathrm{L}) \mathrm{Br}]^{+}$Complexes in $\mathrm{MeCN}$ (L = TPMA, TPMA $^{* 3}$, TPMA $^{\mathrm{NMe} 2}$ )

\begin{tabular}{|cccc|}
\hline & TPMA & TPMA $^{* 3}$ & TPMA $^{\text {NMe2 }}$ \\
\hline${ }^{\mathrm{a}} E_{1 / 2, \mathrm{Cu}}$ & 1.06 & 1.06 & 1.06 \\
$E_{1 / 2, \mathrm{LCu}}$ & $-0.030^{\mathrm{c}}$ & $-0.177^{\mathrm{b}}$ & -0.302 \\
$E_{1 / 2, \mathrm{LCuBr}}$ & -0.240 & -0.420 & -0.554 \\
$E_{1 / 2, \mathrm{Cu}}-E_{1 / 2, \mathrm{LCu}}$ & 1.090 & 1.237 & 1.362
\end{tabular}




$\begin{array}{cccc}E_{1 / 2, \text { LCu }}-E_{1 / 2, \mathrm{LCuBr}} & 0.210 & 0.243 & 0.252 \\ { }^{\mathrm{d}} K_{\text {Disp }, \mathrm{Cu}} & 1.0 \times 10^{-21} & 1.0 \times 10^{-21} & 1.0 \times 10^{-21} \\ { }^{\mathrm{e}} K_{\text {Disp }, \mathrm{LCu}} & <1.0 \times 10^{-4} & <1.0 \times 10^{-4} & <1.0 \times 10^{-4} \\ \beta^{\prime \prime} / \beta^{\prime} & 2.7 \times 10^{18} & 8.1 \times 10^{20} & 1.1 \times 10^{23} \\ \beta^{\prime \prime} /\left(\beta^{\prime}\right)^{2} & <1.0 \times 10^{17} & <1.0 \times 10^{17} & <1.0 \times 10^{17} \\ \beta^{\prime \prime} & >7.1 \times 10^{19} & >6.6 \times 10^{24} & >1.1 \times 10^{29} \\ \beta^{\prime} & >2.7 \times 10^{1} & >8.1 \times 10^{3} & >1.1 \times 10^{6} \\ \beta_{\mathrm{X}, \text { app }}^{\mathrm{II}} / \beta_{\mathrm{X}, \text { app }}^{\mathrm{I}} & 5.3 \times 10^{3} & 1.3 \times 10^{4} & 5.3 \times 10^{3} \\ { }^{\mathrm{f}} K_{\text {ATRP }} & \approx 10^{-5} & \approx 10^{-3} & \approx 10^{-1} \\ k_{\mathrm{a}}(\mathrm{MBrP}) & 2.2 \times 10^{2 \mathrm{~g}} & 8.4 \times 10^{3 \mathrm{~h}} & 1.1 \times 10^{6}\end{array}$

Redox potentials in V vs. SCE; $k_{\mathrm{a}}$ in $\mathrm{M}^{-1} \mathrm{~s}^{-1}$. ${ }^{\mathrm{a}}$ Taken from literature ${ }^{61}$. ${ }^{\mathrm{b}}$ Taken from Ref ${ }^{43}$, ${ }^{\mathrm{C}}$ Taken from Ref $^{46}$ using the conversion factor $E^{\circ}\left(\mathrm{Fc}^{+} / \mathrm{Fc}\right)=0.390 \mathrm{~V}$ vs. SCE. ${ }^{\mathrm{d}}$ From Ref ${ }^{60}$ experimental limiting value of $K_{\text {Disp,LCu. }}{ }^{\mathrm{f}}$ Estimated for acrylates based on values of $E_{1 / 2, \mathrm{LCuBr}}$ based on trend of $E_{1 / 2}$ vs. $K_{\text {ATRP }}{ }^{43} \mathrm{~g}_{\text {From Ref }}{ }^{62}$ ${ }^{\text {h}}$ From Ref $^{31}$.

\section{Assessment of ATRP Activity}

The ability of L/Cu' complexes to activate (macro)alkyl halide bonds is paramount to the success of an ATRP system. The bond dissociation free energy (BDFE) of a $\mathrm{C}-\mathrm{X}(\mathrm{X}=\mathrm{Cl}$ or $\mathrm{Br}$ ) has been correlated to values of $K_{\text {ATRP }}$ via DFT. ${ }^{21,27}$ Generally, the activation reaction is faster (larger values of $k_{\mathrm{a}}$ ) if the resulting radical is more stabilized either through steric or resonance effects.

Electrochemistry is a useful tool in determining kinetic parameters in ATRP. The use of a rotating disk electrode allowed for measurement of $k_{\mathrm{a}}$ and $K_{\text {ATRP }}$ for systems with moderately high activity $\left(k_{\mathrm{a}}<10^{4}\right)$. For more active processes such as in aqueous media ${ }^{63}$ and systems involving highly active catalysts ${ }^{64}$, cyclic voltammetry of copper complexes under catalytic conditions (in the presence of RX) coupled with digital simulations can be used to obtain $k_{a}{ }^{64-66}$

(A)

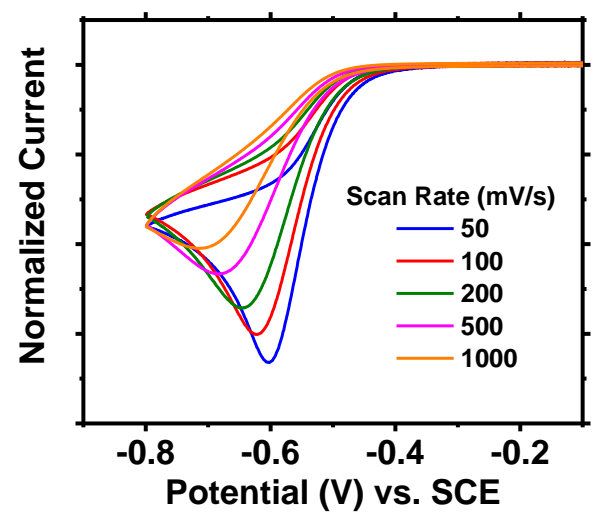

(B)

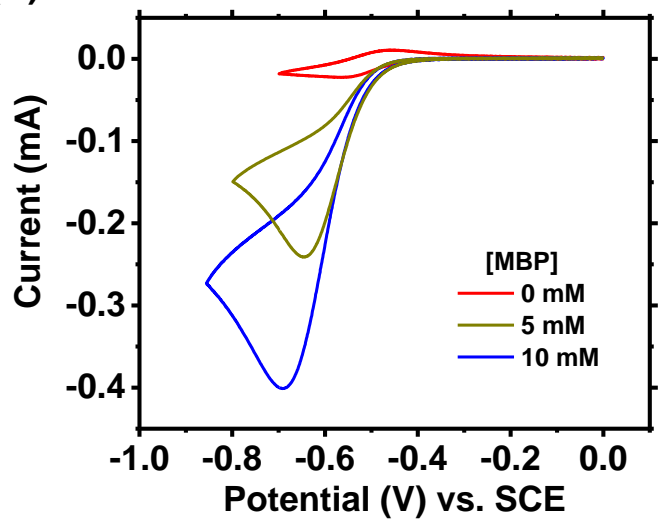


Figure 5 Cyclic voltammograms of [Cu(TPMA $\left.\left.{ }^{\mathrm{NMe} 2}\right) \mathrm{Br}\right]^{+}$in the presence of methyl 2bromopropionate (MBrP; acrylate mimic) at $(A)$ varying scan rates and $(B)$ different $[\mathrm{MBrP}]_{0}$ in $\mathrm{MeCN}$ at scan rate $0.2 \mathrm{~V} \mathrm{~s}^{-1}$ at room temperature. In $(A)$ current was normalized by dividing by square root of the scan rate. $[\mathrm{MBrP}]_{0}:\left[\mathrm{TPMA}^{\mathrm{NMe} 2}\right]_{0}:\left[\mathrm{CuBr}_{2}\right]_{0}:\left[\mathrm{TEMPO}_{0}=0-10: 1: 1: 10 ;\left[\mathrm{CuBr}_{2}\right]_{0}=1\right.$ $\mathrm{mM}$.

As shown in Figure 5A, cyclic voltammetry of the $\left[\mathrm{Cu}\left(\mathrm{TPMA}^{\mathrm{NMe} 2}\right) \mathrm{Br}\right]^{+}$complex was conducted in the presence of methyl 2-bromopropionate (MBrP) and TEMPO. Here, MBrP acted as a small molecule model of acrylate chain-end, while TEMPO was used as a radical trap to prevent the deactivation reaction. The dramatic increase in the cathodic current, as the scan rate decreased, is consistent with previous reports. ${ }^{67}$ The absence of an oxidation peak indicates that the electrochemically generated $\mathrm{Cu}^{\prime}$ was completely consumed in the activation of $\mathrm{MBrP}$, showing the high activity of this catalyst in the activation of acrylates. As shown in Figure S7, simulations of the cyclic voltammetry under catalytic conditions gave a rate coefficient of activation, $k_{\mathrm{a}}$, of $1.1 \times 10^{6} \mathrm{M}^{-1} \mathrm{~s}^{-1}$, which is the largest value reported for this initiator with copper-based ATRP catalysts. As will be shown later, values of $k_{d}$ were calculated to be $5 \times 10^{7} \mathrm{M}^{-1} \mathrm{~s}^{-1}$. Thus, $K_{\text {ATRP }}$ was estimated on the order of $10^{-1}$. This value is consistent with that estimated from the redox potential (Table 2, $K_{\mathrm{ATRP}}=1.0 \times 10^{-1}$ ). This also indicates that deactivation for so active and reducing complexes is still very efficient. These preliminary studies further indicate that this new complex is the most active copper-based ATRP catalyst to date.

Figure $6 \mathrm{~A}$ shows cyclic voltammetry of $\left[\mathrm{Cu}\left(\mathrm{TPMA}^{\mathrm{NMe} 2}\right) \mathrm{Br}\right]^{+}$in the presence of more active ethyl $\alpha$-bromoisobutyrate (EBiB; methacrylate mimic). With [EBiB] $]_{0} \gg$ $\left[\mathrm{Cu}^{\prime \prime}\left(\mathrm{TPMA}^{\mathrm{NMe}}\right) \mathrm{Br}\right]_{0}$ a large increase of the cathodic current and complete disappearance of the anodic peak was observed, similar to the voltammograms in the presence of the less active $\mathrm{MBrP}$. Simulation of the experimental voltammograms gave $k_{\mathrm{a}}=7.2 \times 10^{6} \mathrm{M}^{-1} \mathrm{~s}^{-1}$ indicating that $K_{\text {ATRP }}$ approaches unity. However, at a ratio of $\left[\mathrm{Cu}^{\prime \prime}\left(\mathrm{TPMA}^{\mathrm{NMe} 2}\right) \mathrm{Br}\right]_{0}:[\mathrm{EBiB}]_{0}=1$, an interesting cyclic voltammogram was observed where the cathodic wave splits into two peaks (Figure 6B). This particular phenomenon is attributed to "total catalysis", which is usually found for extremely efficient catalysts with rate constants for bimolecular reactions $>10^{6} \mathrm{M}^{-1} \mathrm{~s}^{-1}$. Indeed, in this case, only an infinitesimal amount of $L / C u^{\prime}$ is required for the complete reduction of $R B r$, 
giving a first irreversible peak at $E>E_{1 / 2, \mathrm{LC} C \mathrm{Br}}$ due to the very fast catalytic reduction of $\mathrm{EBiB}$. On the other hand, the electrochemical reduction of $\left[\mathrm{Cu}\left(\mathrm{TPMA}^{\mathrm{NMe} 2}\right) \mathrm{Br}\right]^{+}$is still reversible since the majority of the catalyst is not involved in the electrocatalytic process. Overall, these results show the extreme reactivity of $\left[\mathrm{Cu}\left(\mathrm{TPMA}^{\mathrm{NMe} 2}\right) \mathrm{Br}\right]^{+}$, which can be used in ATRP with unprecedentedly low ppm concentrations.

(A)

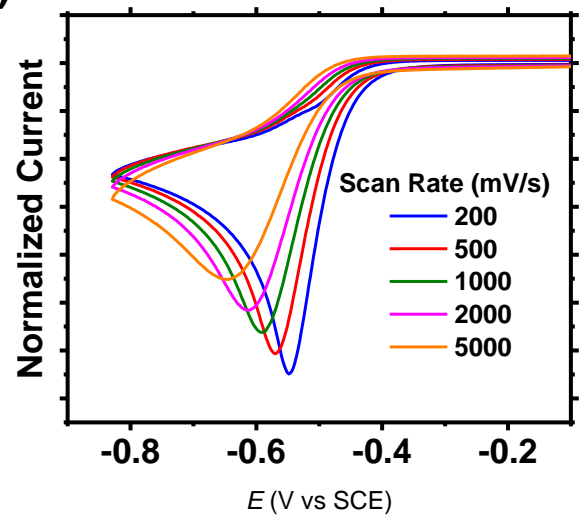

(B)

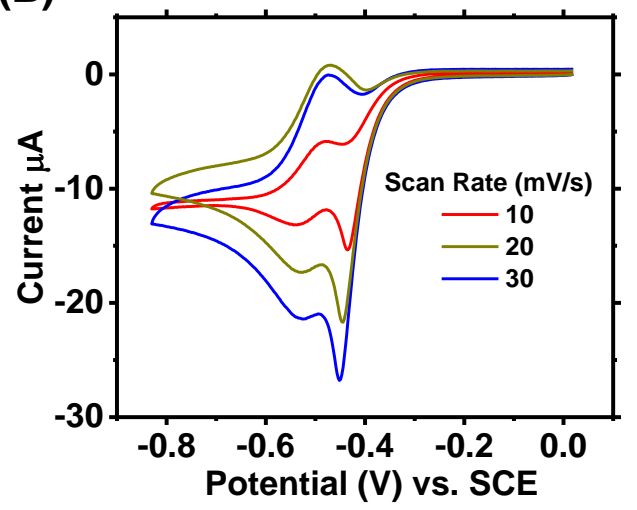

Figure 6. Cyclic voltammograms of $1 \mathrm{mM}\left[\mathrm{Cu}\left(\mathrm{TPMA}^{\mathrm{NMe} 2}\right) \mathrm{Br}\right]^{+}$in the presence of ethyl $\alpha$ bromoisobutyrate (EBiB; methacrylate mimic) at (A) $5 \mathrm{mM}$ (B) $1 \mathrm{mM}$ concentration in MeCN at at room temperature. In $(A)$ current was normalized by dividing by square root of the scan rate. $[\mathrm{EBiB}]_{0}:\left[\mathrm{TPMA}^{\mathrm{NMe} 2}\right]_{0}:\left[\mathrm{CuBr}_{2}\right]_{0}:[\mathrm{TEMPO}]_{0}=1-5: 1: 1: 10$. Fix $\mathrm{x}$ axis

\section{Low ppm ATRP of Acrylates}

To assess the efficiency of the $\left[\mathrm{Cu}\left(\mathrm{TPMA}^{\mathrm{NMe} 2}\right) \mathrm{Br}\right]^{+}$catalyst, various forms of ATRP with activator regeneration were conducted. First, ICAR ATRP was conducted at catalyst loadings ranging from 10 to 100 ppm relative to monomer with 2,2'-azobis(2-isobutyronitrile) (AIBN) as radical initiator. ${ }^{68}$ As shown in Figure 7, linear semi-logarithmic plots vs. time were observed at all catalyst loadings. This is consistent with previously established ICAR kinetics with bimolecular termination for which the amount of catalyst does not change the rate of polymerization as shown in Eq 5, where $f$ is initiator efficiency of AIBN, $k_{\text {azo }}$ is the decomposition rate coefficient and $k_{\mathrm{t}}$ is the rate coefficient of radical-radical termination. ${ }^{69-70}$

$$
\left[\mathrm{R}^{\bullet}\right]=\sqrt{\frac{f k_{\mathrm{azo}}[\mathrm{AIBN}]}{k_{\mathrm{t}}}}
$$


$\left[\mathrm{R}^{\bullet}\right]=\frac{f k_{\mathrm{azo}}[\mathrm{AIBN}]}{k_{\mathrm{CRT}}^{\mathrm{app}}\left[\mathrm{Cu}^{\mathrm{I}}\right]}$

After 4 hours, $>90 \%$ conversion was achieved for all reactions with a linear increase of molecular weights with conversion, typical of a well-controlled polymerization. While the rate of polymerization was unaffected by the initial amount of catalyst, molecular weight distributions gradually broadened upon decreasing catalyst concentration (Figure S9). This is attributed to decreased rate of deactivation relative to propagation. Although the initial amount of catalyst does not affect the rate of polymerization, at lower catalyst loadings there is less deactivator complex to reversibly trap radicals. This causes more monomer additions per activation cycle and thus a broadening of the molecular weight distribution. (cf. Eq. 7)

(A)

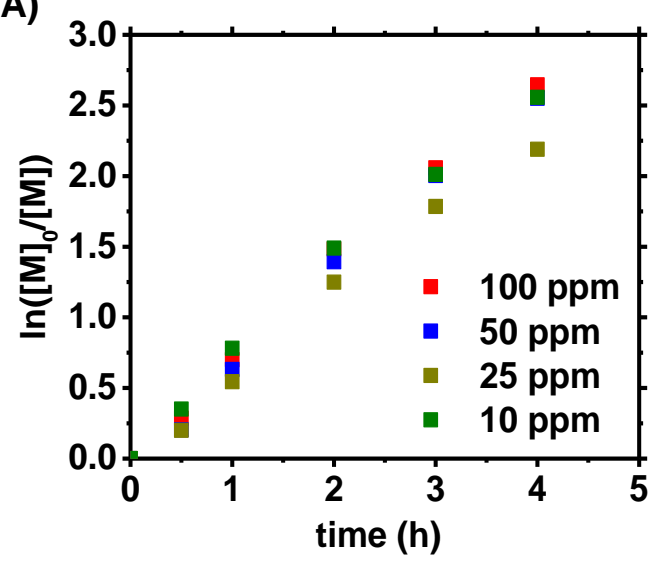

(B)

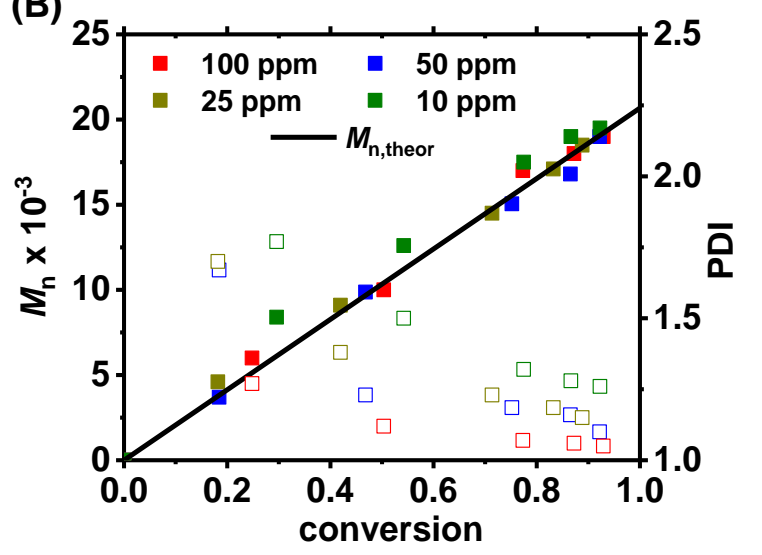

Figure 7 A) Semi-logarithmic plots and B) $M_{n}$ and $\emptyset$ vs. conversion for the ICAR ATRP of $n$-butyl acrylate (BA) at different [Cu" $\left.\left(\mathrm{TPMA}^{\mathrm{NMe}}\right) \mathrm{Br}\right][\mathrm{Br}$ ] loadings under the initial conditions $[\mathrm{BA}]_{0}:[\mathrm{EBiB}]_{0}:\left[\mathrm{L} / \mathrm{CUBr}_{2}\right]_{0}:\left[\mathrm{TPMA}^{\mathrm{NMe}}\right]_{0}:[\mathrm{AIBN}]_{0}=160: 1: 0.016-0.0016: 0.2$ in anisole at $60^{\circ} \mathrm{C}$; catalyst loadings in ppm vs. monomer; $[B A]_{0}=4.5 \mathrm{M}$.

An interesting point to note is that, according to the kinetic plots presented in Figure 7A and PREDICI simulations provided in the SI, bimolecular radical termination (RT) should dominate catalytic radical termination (CRT), contrary to previous studies with other ATRP catalysts. ${ }^{13}$ If CRT would significantly contribute to overall termination, the polymerization kinetics would depend on catalyst concentration (Eq. 6), where $k_{\mathrm{CRT}}^{\mathrm{app}}$ is the apparent CRT rate coefficient. ${ }^{71}$ This is because, as shown in Scheme 3, CRT requires the coordination of a propagating radical $\left({ }^{\bullet} P_{n}\right)$ to the $L / C u^{\prime}$ complex to form a $L / C u^{11}-P_{n}$ organometallic species. ${ }^{71}$ 


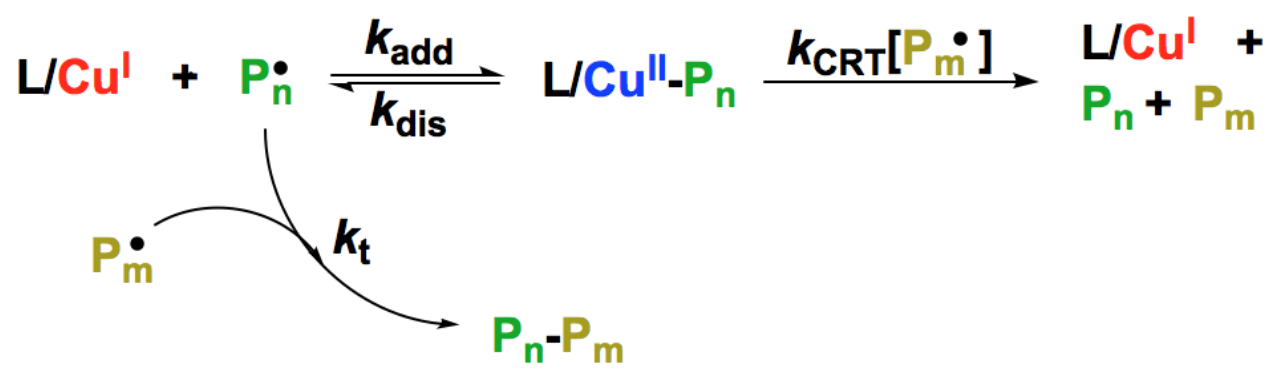

Scheme 3 Interplay between conventional bimolecular radical termination (RT) and catalytic radical termination via the reactive $L / C u^{\prime \prime}-P_{n}$ intermediate in ATRP of acrylates.

Since the L/Cu' concentration in ICAR ATRP is governed by the dynamic ATRP equilibrium $^{72}$ (Scheme 1), and considering the very high values of $K_{\mathrm{ATRP}} \approx 10^{-1}$ for this system, the amount of $\mathrm{TPMA}^{\mathrm{NMe}} / \mathrm{Cu}^{\prime}$ present in solution is calculated to be $9.6 \times 10^{-10}$ at equilibrium (See Supporting Information for calculation). ${ }^{72}$ In other words, a radical will kinetically terminate with a second radical faster than with the trace amounts of $\mathrm{TPMA}^{\mathrm{NMe} 2} / \mathrm{Cu}$. This should still happen, even if addition of a radical to TPMA ${ }^{\mathrm{NMe} 2} / \mathrm{Cu}^{\prime}$ occurs at diffusion controlled rates $\left(k_{\text {add }}=10^{8} \mathrm{M}^{-1} \mathrm{~s}^{-1}\right)$. This is not the case of less active catalysts such as TPMA-based systems $\left(K_{\text {ATRP }} \approx 10^{-5}\right)^{62}$ where CRT dominates because of a relatively higher concentration of TPMA/Cu' of $1.8 \times 10^{-6} \mathrm{M}$. As shown in Figure S10, these findings are supported by PREDICI simulations: the much more active TPMA ${ }^{\mathrm{NMe}}$-based system kinetically suppressed CRT because only a small fraction of $\mathrm{TPMA}^{\mathrm{NMe} 2} / \mathrm{Cu}^{\prime}$ is present in solution, resulting in a relatively larger fraction of living chains compared to less active systems.

Then, $\mathrm{Ag}^{0}$ ATRP, a form of ARGET ATRP, was conducted to further test the scope of the newly synthesized catalyst. $\mathrm{Ag}^{0} \mathrm{ATRP}$ employs silver wire to heterogeneously reduce $\mathrm{L} / \mathrm{Cu}$ " to $\mathrm{L} / \mathrm{Cu}^{\prime}$, with oxidation of $\mathrm{Ag}^{0}$ to $\mathrm{Ag}^{\mathrm{B}} \mathrm{Br}^{11}$ As shown in Figure 8, the $\mathrm{TPMA}^{\mathrm{NMe} 2}$ catalyst successfully polymerized MA via $\mathrm{Ag}^{0} \mathrm{ARGET}$ ATRP using as little as $10 \mathrm{ppm}$ of catalyst relative to monomer. However, at 5 ppm, the polymerization was no longer living as confirmed by the molecular weights decreasing with conversion and high $€$ values $(>1.5)$. Since the rate of $\mathrm{Ag}^{0} \mathrm{ARGET}$ ATRP depends on the rate of $\mathrm{Cu}^{\prime}$ generation, the linear semi-logarithmic kinetic plots showed that $\mathrm{Cu}^{\prime \prime}$ was still reduced but unable to efficiently deactivate radicals. This is because, at such low catalyst concentrations, the rate of propagation and termination are competing with the rate of 
deactivation. Thus, it is likely that $10 \mathrm{ppm}$ is around the lowest possible limits to achieve a wellcontrolled polymerization in copper catalyzed ATRP of acrylates. Nevertheless, unprecedented control was achieved using as little as $10 \mathrm{ppm}$ of catalyst for the polymerization of acrylates. The nearly colorless nature of the polymerization solution at 10 ppm can be seen in Figure $\mathbf{8 C}$.
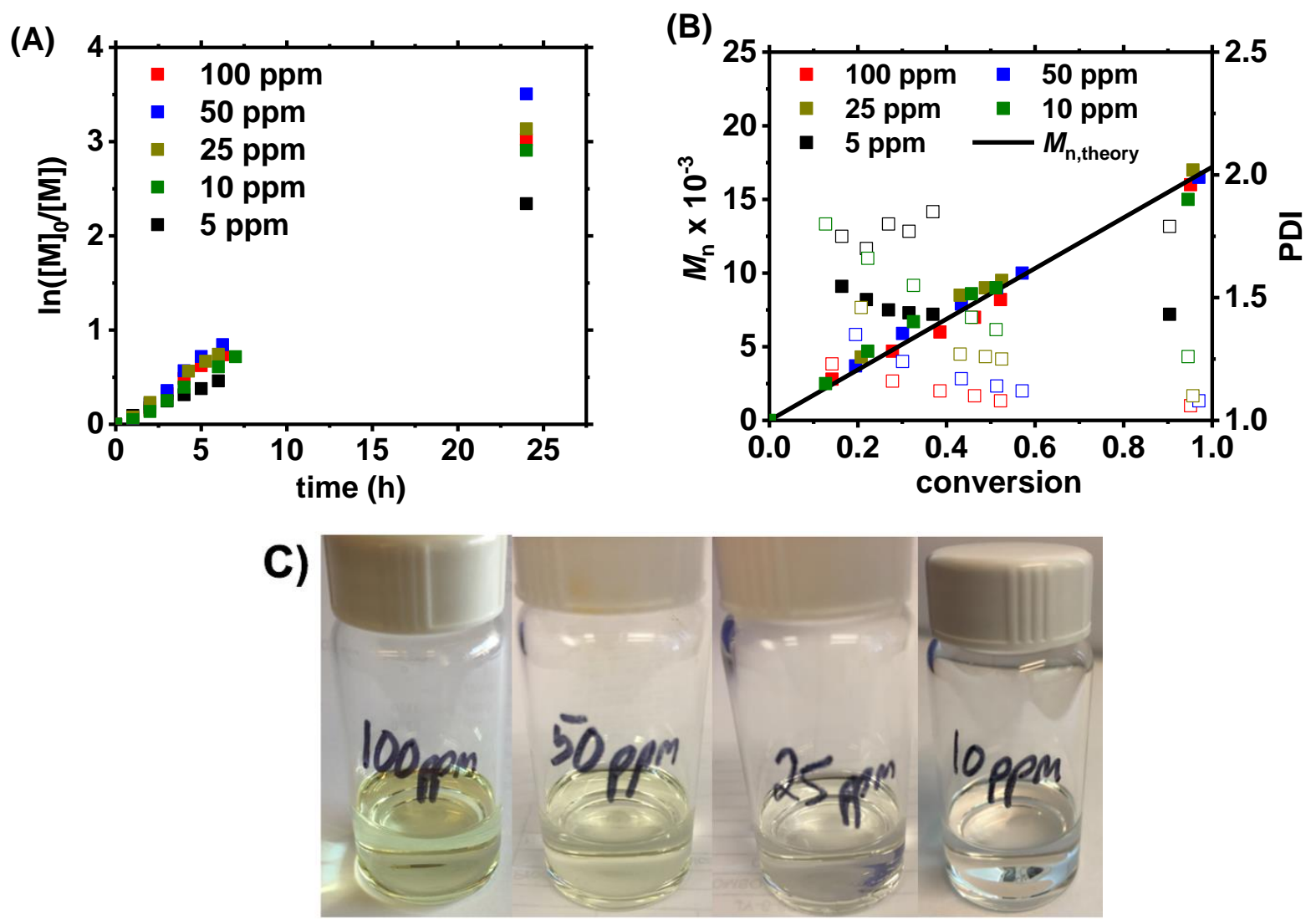

Figure 8 A) Semi-logarithmic plots and B) $M_{n}$ and $\emptyset$ vs. conversion for the $\mathrm{Ag}^{0}$ ATRP of methyl acrylate (MA) at different loadings of [Cu" $\left.\left(\mathrm{TPMA}^{\mathrm{NMe}}\right) \mathrm{Br}\right][\mathrm{Br}]$ under the initial conditions $[\mathrm{MA}]_{0}:[\mathrm{EBiB}]_{0}:\left[\mathrm{Cu}\right.$ "(TPMA $\left.\left.{ }^{\mathrm{NMe2}}\right) \mathrm{Br}\right][\mathrm{Br}]_{0}=200: 1: 0.02-0.002$ with $10 \mathrm{~cm} \mathrm{Ag}^{0}$ wire $(\mathrm{SA} / \mathrm{V})=0.53 \mathrm{~cm}^{-1}$ in $\mathrm{DMF}$ at $50^{\circ} \mathrm{C}$; catalyst loadings in ppm vs. monomer; $[\mathrm{MA}]_{0}=5.75 \mathrm{M}$ and $\mathrm{C}$ ) pictures of polymerization solution at decreasing catalyst loadings of [Cu" $\left.\left(\mathrm{TPMA}^{\mathrm{NMe}}\right) \mathrm{Br}\right][\mathrm{Br}]$.

Using the results from the two polymerization systems shown in Figures 6 \& 7, one can estimate the rate coefficient of deactivation, $k_{\mathrm{d}}$, according to Eq $\mathbf{7}$ where DP is the degree of polymerization, $k_{\mathrm{p}}$ is the propagation rate constant, ${ }^{73}$ and $p$ is monomer conversion. ${ }^{4}$ 


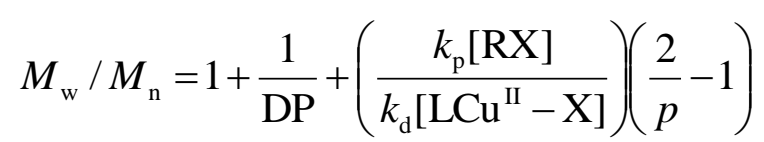

Due to the negligible amount of termination, it has been assumed that $[R X]=[R X]_{0}$. Furthermore, since the $K_{\text {ATRP }}$ is so large, it can be assumed that essentially all copper is in the form of $\mathrm{L} / \mathrm{Cu}^{\prime \prime}-\mathrm{X}$ and therefore $\left[\mathrm{L} / \mathrm{Cu}^{\mathrm{I}}-\mathrm{X}\right]=\left[\mathrm{L} / \mathrm{Cu}^{\prime \prime}-\mathrm{X}\right]_{0}$. Using the final dispersity data of the polymerizations in Figures 6 \& 8, $k_{d}=5.4( \pm 1.7) \times 10^{7} \mathrm{M}^{-1} \mathrm{~s}^{-1}$ was obtained which gives an estimated value of $K_{\text {ATRP }}=2.2 \times 10^{-2}$ for acrylate systems. This indicates that the degree of substitution and redox potential of pyridinic-based catalysts have very little effect on $k_{\mathrm{d}}$. Instead, only the total amount of $\mathrm{Cu}^{\prime \prime}-\mathrm{X}$ deactivator, which is regulated by $\left[\mathrm{Cu}^{\prime \prime}\right]_{0}$ and $K_{\mathrm{ATRP}}$, will define the level of control in a particular ATRP system with activator regeneration.

\section{Comparison of TPMA ${ }^{\mathrm{NMe} 2}$ to Other Ligands in ATRP}

As shown in Figure 8, the redox potential scales linearly with $\log \left(K_{\mathrm{ATRP}}\right)$ for EBiB in MeCN at room temperature for a variety of ligands (Figure S11 for structures of ligands). Based on $E_{1 / 2}$ values, the newly synthesized TPMA ${ }^{\mathrm{NMe} 2}$-based catalyst $\left(E_{1 / 2}=-554 \mathrm{mV}\right)$ is almost 10 billion times more active than seminal bpy-based catalyst $\left(E_{1 / 2}=+30 \mathrm{mV}\right)$. Even looking at catalysts which are widely used for low ppm ATRP, the TPMA ${ }^{\text {NMe2 }}$-based system is $\approx 300,000$ and 30,000 times more active than the TPMA $\left(E_{1 / 2}=-240 \mathrm{mV}\right)$ and $\mathrm{Me}_{6} \operatorname{TREN}\left(E_{1 / 2}=-300 \mathrm{mV}\right)$ based catalysts, respectively. Unfortunately, with such a highly active catalyst as $\left[\mathrm{Cu}\left(\mathrm{TPMA}^{\mathrm{NMe}}\right)\right]^{+}$, activation of alkyl halides approaches diffusion controlled limits $\left(k_{\mathrm{a}}>10^{6} \mathrm{M}^{-1} \mathrm{~s}^{-1}\right)$, and with already diffusion controlled deactivation rates $\left(k_{d}=>10^{7} \mathrm{M}^{-1} \mathrm{~s}^{-1}\right)$, values of $K_{\text {ATRP }}$ begin to approach unity. This would mean that for commonly used monomers such as acrylates and methacrylates, this catalytic system may be the upper limit of activity since the only way to further increase $K_{\text {ATRP }}$ would be to decrease $k_{\mathrm{d}}$. This is not best since the control achieved in ATRP is due to fast rates of deactivation. Encouragingly, the high ATRP activity provided by the

$\mathrm{TPMA}^{\mathrm{NMe} 2}$-based catalyst can open the possibility to polymerize less active monomers such as vinyl acetate and $N$-vinylpyrrolidone which have historically fallen victim to too low values of $K_{\text {ATRP. }}$ 


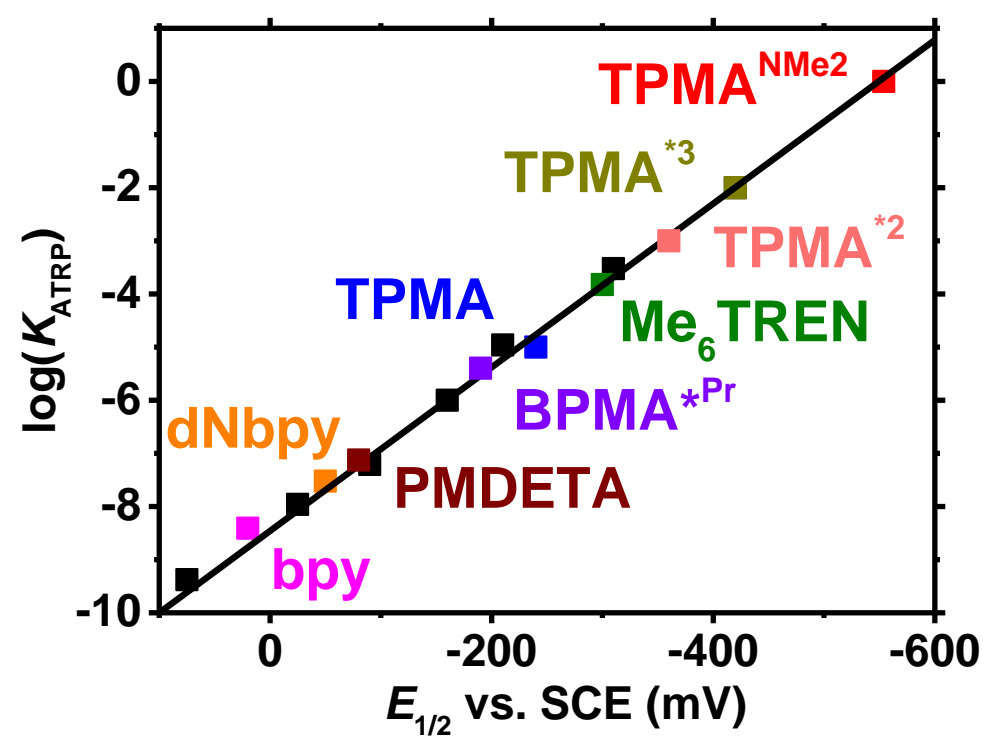

Figure 9 Redox potential $\left(E_{1 / 2}\right)$ vs. $\log \left(K_{\text {ATRP }}\right)$ for various ATRP catalysts complexed by multidentate nitrogen-based ligands. Values for $E_{1 / 2}$ have previously been determined experimentally vs. an SCE electrode in MeCN at room temperature. Values of $K_{\text {ATRP }}$ are for ethyl $\alpha$-bromoisobutyrate (EBiB; methacrylate mimic) in $\mathrm{MeCN}$ at room temperature. Structures of all ligands are shown in Figure S11.

\section{Conclusions}

The synthesis of a new ATRP catalyst employing the $p$-dimethylamino substituted TPMA ligand, tris[(4-dimethylaminiopyridyl)methyl]amine $\left(\mathrm{TPMA}^{\mathrm{NMe} 2}\right)$, is reported. Variable temperature NMR showed a fluxional $\mathrm{Cu}^{\prime}$ complex with rapid ligand exchange. In the solid state, the $\left[\mathrm{Cu}^{\prime \prime}\left(\mathrm{TPMA}^{\mathrm{NMe} 2}\right) \mathrm{Br}\right]^{+}$complex exhibited nearly perfect trigonal bipyramidal geometry. UV-Vis and EPR confirmed that this geometry was retained in solution. Electrochemical measurements showed a quasi-reversible TPMA ${ }^{\mathrm{NMe} 2} \mathrm{Cu}^{1 / l l}$ couple indicating small geometric rearrangement throughout the redox cycle. Stability constants for $\mathrm{Cu}^{\prime}$ and $\mathrm{Cu}^{\prime \prime}$ were comparable to other copper ATRP catalysts in MeCN. Electrochemistry was also utilized to assess the activation of methyl 2-bromopropionate (MBrP; acrylate mimic) and ethyl $\alpha$ bromoisobutyrate, for which a rate coefficient of activation was measured as $k_{\mathrm{a}}=1.1 \times 10^{6} \mathrm{M}^{-1} \mathrm{~s}^{-}$ ${ }^{1}$ and $7.2 \times 10^{6} \mathrm{M}^{-1} \mathrm{~s}^{-1}$, respectively. This leads to an estimation of $K_{\text {ATRP }}=2.2 \times 10^{-2}$ and $7.2 \times 10^{-1}$, respectively which indicated this is the most active ATRP catalyst to date. A large value of $k_{d}>$ $10^{7} \mathrm{M}^{-1} \mathrm{~s}^{-1}$ was calculated and indicated that the catalyst is also a good deactivator. Both ICAR and $\mathrm{Ag}^{0} \mathrm{ATRP}$ of acrylates were well-controlled using as little as $10 \mathrm{ppm}$ of catalyst relative to 
monomer. Encouragingly, due to the high values of $K_{\mathrm{ATRP}}$ and low [TPMA $\left.{ }^{\mathrm{NMe} 2} / \mathrm{Cu}^{\prime}\right]$, unwanted side reactions involving $\mathrm{Cu}^{\prime}$ such as catalytic radical termination (CRT) are suppressed leading to higher chain-end functionality. Furthermore, this catalyst can potentially allow for the successful ATRP of less active monomers. Investigations in this direction are currently ongoing in our laboratories.

\section{AUTHOR INFORMATION}

\section{Corresponding Author:}

*(K.M.) Email: km3b@andrew.cmu.edu

${ }^{\circ}$ T.R. and M.F. contributed equally.

\section{Notes}

The authors declare no competing financial interest.

\section{ACKNOWLEDGEMENTS}

Support from the NSF (CHE 1707490) is acknowledged. We thank the Centre National de la Recherche Scientifique (CNRS) for support through the PICS06782 grant and through the Laboratoire International Associé (LIA) "Laboratory of Coordination Chemistry for Controlled Radical Polymerization". We are also grateful to the French Embassy in Washington D.C. for a Chateaubriand Fellowship to T.R. We would like to acknowledge Mateusz Olszewski for designing the graphical abstract for this manuscript.

\section{REFERENCES}

1. Matyjaszewski, K.; Xia, J., Atom Transfer Radical Polymerization. Chemical Reviews 2001, 101 (9), 2921-2990.

2. Wang, J.-S.; Matyjaszewski, K., Controlled/"living" radical polymerization. atom transfer radical polymerization in the presence of transition-metal complexes. Journal of the American Chemical Society 1995, 117 (20), 5614-5615.

3. Kato, M.; Kamigaito, M.; Sawamoto, M.; Higashimura, T., Polymerization of Methyl Methacrylate with the Carbon Tetrachloride/Dichlorotris(triphenylphosphine)ruthenium(II)/Methylaluminum Bis(2,6-di-tert-butylphenoxide) Initiating System: Possibility of Living Radical Polymerization. Macromolecules 1995, 28 (5), 1721-1723.

4. Matyjaszewski, K., Atom Transfer Radical Polymerization (ATRP): Current Status and Future Perspectives. Macromolecules 2012, 45 (10), 4015-4039. 
5. Wang, J.-S.; Matyjaszewski, K., Controlled/"Living" Radical Polymerization. Halogen Atom Transfer Radical Polymerization Promoted by a $\mathrm{Cu}(\mathrm{I}) / \mathrm{Cu}(\mathrm{II})$ Redox Process. Macromolecules 1995, 28 (23), 7901-7910.

6. Matyjaszewski, K.; Tsarevsky, N. V., Macromolecular Engineering by Atom Transfer Radical Polymerization. Journal of the American Chemical Society 2014, 136 (18), 6513-6533.

7. Matyjaszewski, K.; Jakubowski, W.; Min, K.; Tang, W.; Huang, J.; Braunecker, W. A.; Tsarevsky, N. V., Diminishing catalyst concentration in atom transfer radical polymerization with reducing agents. Proceedings of the National Academy of Sciences 2006, 103 (42), 15309-15314. 8. Konkolewicz, D.; Magenau, A. J. D.; Averick, S. E.; Simakova, A.; He, H.; Matyjaszewski, K., ICAR ATRP with ppm Cu Catalyst in Water. Macromolecules 2012, 45 (11), 4461-4468.

9. Chan, N.; Cunningham, M. F.; Hutchinson, R. A., ARGET ATRP of Methacrylates and Acrylates with Stoichiometric Ratios of Ligand to Copper. Macromolecular Chemistry and Physics 2008, 209 (17), 1797-1805.

10. Jakubowski, W.; Matyjaszewski, K., Activators Regenerated by Electron Transfer for Atom-Transfer Radical Polymerization of (Meth)acrylates and Related Block Copolymers. Angewandte Chemie 2006, 118 (27), 4594-4598.

11. Williams, V. A.; Ribelli, T. G.; Chmielarz, P.; Park, S.; Matyjaszewski, K., A Silver Bullet: Elemental Silver as an Efficient Reducing Agent for Atom Transfer Radical Polymerization of Acrylates. Journal of the American Chemical Society 2015, 137 (4), 1428-1431.

12. Konkolewicz, D.; Wang, Y.; Zhong, M.; Krys, P.; Isse, A. A.; Gennaro, A.; Matyjaszewski, K., Reversible-Deactivation Radical Polymerization in the Presence of Metallic Copper. A Critical Assessment of the SARA ATRP and SET-LRP Mechanisms. Macromolecules 2013, 46 (22), 8749-8772.

13. Ribelli, T. G.; Konkolewicz, D.; Bernhard, S.; Matyjaszewski, K., How are Radicals (Re)Generated in Photochemical ATRP? Journal of the American Chemical Society 2014, 136 (38), 13303-13312.

14. Pan, X.; Tasdelen, M. A.; Laun, J.; Junkers, T.; Yagci, Y.; Matyjaszewski, K., Photomediated controlled radical polymerization. Progress in Polymer Science 2016, 62, 73-125. 15. Anastasaki, A.; Nikolaou, V.; Zhang, Q.; Burns, J.; Samanta, S. R.; Waldron, C.; Haddleton, A. J.; McHale, R.; Fox, D.; Percec, V.; Wilson, P.; Haddleton, D. M., Copper(II)/Tertiary Amine Synergy in Photoinduced Living Radical Polymerization: Accelerated Synthesis of $\omega$-Functional and $\alpha, \omega$-Heterofunctional Poly(acrylates). Journal of the American Chemical Society 2014, 136 (3), 1141-1149.

16. Discekici, E. H.; Anastasaki, A.; Kaminker, R.; Willenbacher, J.; Truong, N. P.; Fleischmann, C.; Oschmann, B.; Lunn, D. J.; Read de Alaniz, J.; Davis, T. P.; Bates, C. M.; Hawker, C. J., Light-Mediated Atom Transfer Radical Polymerization of Semi-Fluorinated (Meth)acrylates: Facile Access to Functional Materials. Journal of the American Chemical Society 2017, 139 (16), 5939-5945.

17. Anastasaki, A.; Oschmann, B.; Willenbacher, J.; Melker, A.; Van Son, M. H. C.; Truong, N. P.; Schulze, M. W.; Discekici, E. H.; McGrath, A. J.; Davis, T. P.; Bates, C. M.; Hawker, C. J., One-Pot Synthesis of ABCDE Multiblock Copolymers with Hydrophobic, Hydrophilic, and SemiFluorinated Segments. Angewandte Chemie International Edition 2017, 56 (46), 14483-14487.

18. Chmielarz, P.; Fantin, M.; Park, S.; Isse, A. A.; Gennaro, A.; Magenau, A. J. D.; Sobkowiak, A.; Matyjaszewski, K., Electrochemically mediated atom transfer radical polymerization (eATRP). Progress in Polymer Science 2017, 69, 47-78. 
19. Wang, Z.; Pan, X.; Li, L.; Fantin, M.; Yan, J.; Wang, Z.; Wang, Z.; Xia, H.; Matyjaszewski, K., Enhancing Mechanically Induced ATRP by Promoting Interfacial Electron Transfer from Piezoelectric Nanoparticles to Cu Catalysts. Macromolecules 2017, 50 (20), 7940-7948.

20. Mohapatra, H.; Kleiman, M.; Esser-Kahn, A. P., Mechanically controlled radical polymerization initiated by ultrasound. Nat Chem 2017, 9 (2), 135-139.

21. Lin, C. Y.; Coote, M. L.; Gennaro, A.; Matyjaszewski, K., Ab Initio Evaluation of the Thermodynamic and Electrochemical Properties of Alkyl Halides and Radicals and Their Mechanistic Implications for Atom Transfer Radical Polymerization. Journal of the American Chemical Society 2008, 130 (38), 12762-12774.

22. Coessens, V.; Pintauer, T.; Matyjaszewski, K., Functional polymers by atom transfer radical polymerization. Progress in Polymer Science 2001, 26 (3), 337-377.

23. Tang, W.; Tsarevsky, N. V.; Matyjaszewski, K., Determination of Equilibrium Constants for Atom Transfer Radical Polymerization. Journal of the American Chemical Society 2006, 128 (5), 1598-1604.

24. Tsarevsky, N. V.; Braunecker, W. A.; Tang, W.; Matyjaszewski, K., The atom transfer radical polymerization equilibrium: structural and medium effects. ACS Symposium Series 2009, 1023 (Controlled/Living Radical Polymerization: Progress in ATRP), 85-96.

25. Braunecker, W. A.; Tsarevsky, N. V.; Gennaro, A.; Matyjaszewski, K., Thermodynamic Components of the Atom Transfer Radical Polymerization Equilibrium: Quantifying Solvent Effects. Macromolecules 2009, 42 (17), 6348-6360.

26. Tang, W.; Kwak, Y.; Braunecker, W.; Tsarevsky, N. V.; Coote, M. L.; Matyjaszewski, K., Understanding Atom Transfer Radical Polymerization: Effect of Ligand and Initiator Structures on the Equilibrium Constants. Journal of the American Chemical Society 2008, 130 (32), 1070210713.

27. Gillies, M. B.; Matyjaszewski, K.; Norrby, P.-O.; Pintauer, T.; Poli, R.; Richard, P., A DFT Study of R-X Bond Dissociation Enthalpies of Relevance to the Initiation Process of Atom Transfer Radical Polymerization. Macromolecules 2003, 36 (22), 8551-8559.

28. Tang, W.; Matyjaszewski, K., Effect of Ligand Structure on Activation Rate Constants in ATRP. Macromolecules 2006, 39 (15), 4953-4959.

29. Tsarevsky, N. V.; Braunecker, W. A.; Vacca, A.; Gans, P.; Matyjaszewski, K., Competitive Equilibria in Atom Transfer Radical Polymerization. Macromolecular Symposia 2007, 248 (1), 60-70.

30. Rorabacher, D. B., Electron Transfer by Copper Centers. Chemical Reviews 2004, 104 (2), 651-698.

31. Schroder, K.; Mathers, R. T.; Buback, J.; Konkolewicz, D.; Magenau, A. J. D.; Matyjaszewski, K., Substituted Tris(2-pyridylmethyl)amine Ligands for Highly Active ATRP Catalysts. ACS Macro Letters 2012, 1 (8), 1037-1040.

32. Lee, J. Y.; Peterson, R. L.; Ohkubo, K.; Garcia-Bosch, I.; Himes, R. A.; Woertink, J.; Moore, C. D.; Solomon, E. I.; Fukuzumi, S.; Karlin, K. D., Mechanistic Insights into the Oxidation of Substituted Phenols via Hydrogen Atom Abstraction by a Cupric-Superoxo Complex. Journal of the American Chemical Society 2014, 136 (28), 9925-9937.

33. Magenau, A. J. D.; Kwak, Y.; Schröder, K.; Matyjaszewski, K., Highly Active BipyridineBased Ligands for Atom Transfer Radical Polymerization. ACS Macro Letters 2012, 1 (4), 508512 .

34. Zhang, C. X.; Kaderli, S.; Costas, M.; Kim, E.-i.; Neuhold, Y.-M.; Karlin, K. D.; Zuberbühler, A. D., Copper(I)-Dioxygen Reactivity of $[(\mathrm{L}) \mathrm{CuI}]+\quad(\mathrm{L}=\operatorname{Tris}(2-$ 
pyridylmethyl)amine): Kinetic/Thermodynamic and Spectroscopic Studies Concerning the Formation of $\mathrm{Cu}-\mathrm{O} 2$ and $\mathrm{Cu} 2-\mathrm{O} 2$ Adducts as a Function of Solvent Medium and 4-Pyridyl Ligand Substituent Variations. Inorganic Chemistry 2003, 42 (6), 1807-1824.

35. Comba, P.; Morgen, M.; Wadepohl, H., Tuning of the Properties of Transition-Metal Bispidine Complexes by Variation of the Basicity of the Aromatic Donor Groups. Inorganic Chemistry 2013, 52 (11), 6481-6501.

36. Kim, S.; Lee, J. Y.; Cowley, R. E.; Ginsbach, J. W.; Siegler, M. A.; Solomon, E. I.; Karlin, K. D., A N3S(thioether)-Ligated CuII-Superoxo with Enhanced Reactivity. Journal of the American Chemical Society 2015, 137 (8), 2796-2799.

37. Solomon, E. I.; Sundaram, U. M.; Machonkin, T. E., Multicopper Oxidases and Oxygenases. Chemical Reviews 1996, 96 (7), 2563-2606.

38. Solomon, E. I.; Heppner, D. E.; Johnston, E. M.; Ginsbach, J. W.; Cirera, J.; Qayyum, M.; Kieber-Emmons, M. T.; Kjaergaard, C. H.; Hadt, R. G.; Tian, L., Copper Active Sites in Biology. Chemical Reviews 2014, 114 (7), 3659-3853.

39. Wilmot, C. M.; Hajdu, J.; McPherson, M. J.; Knowles, P. F.; Phillips, S. E. V., Visualization of Dioxygen Bound to Copper During Enzyme Catalysis. Science 1999, 286 (5445), 1724-1728.

40. Solomon, E. I.; Chen, P.; Metz, M.; Lee, S.-K.; Palmer, A. E., Oxygen Binding, Activation, and Reduction to Water by Copper Proteins. Angewandte Chemie International Edition 2001, 40 (24), 4570-4590.

41. Decker, H.; Dillinger, R.; Tuczek, F., How Does Tyrosinase Work? Recent Insights from Model Chemistry and Structural Biology. Angewandte Chemie International Edition 2000, 39 (9), 1591-1595.

42. Fry, H. C.; Lucas, H. R.; Narducci Sarjeant, A. A.; Karlin, K. D.; Meyer, G. J., Carbon Monoxide Coordination and Reversible Photodissociation in Copper(I) Pyridylalkylamine Compounds. Inorganic Chemistry 2008, 47 (1), 241-256.

43. Kaur, A.; Ribelli, T. G.; Schröder, K.; Matyjaszewski, K.; Pintauer, T., Properties and ATRP Activity of Copper Complexes with Substituted Tris(2-pyridylmethyl)amine-Based Ligands. Inorganic Chemistry 2015, 54 (4), 1474-1486.

44. Wang, Y.; Zhong, M.; Zhu, W.; Peng, C.-H.; Zhang, Y.; Konkolewicz, D.; Bortolamei, N.; Isse, A. A.; Gennaro, A.; Matyjaszewski, K., Reversible-Deactivation Radical Polymerization in the Presence of Metallic Copper. Comproportionation-Disproportionation Equilibria and Kinetics. Macromolecules 2013, 46 (10), 3793-3802.

45. Mason, J., Patterns of nuclear magnetic shielding of transition-metal nuclei. Chemical Reviews 1987, 87 (6), 1299-1312.

46. Eckenhoff, W. T.; Garrity, S. T.; Pintauer, T., Highly Efficient Copper-Mediated AtomTransfer Radical Addition (ATRA) in the Presence of Reducing Agent. European Journal of Inorganic Chemistry 2008, 2008 (4), 563-571.

47. Hsu, S. C. N.; Chien, S. S. C.; Chen, H. H. Z.; Chiang, M. Y., Synthesis and Characterization of Copper(I) Complexes Containing Tri(2-Pyridylmethyl)Amine Ligand. Journal of the Chinese Chemical Society 2007, 54 (3), 685-692.

48. Kitagawa, S.; Munakata, M., Binuclear copper(I) complexes which reversibly react with carbon monoxide. 1. Di-.mu.-halogeno-bis(2,2'-bipyridine)dicopper(I) and its derivatives. Inorganic Chemistry 1981, 20 (7), 2261-2267.

49. Kitagawa, S.; Munakata, M.; Miyaji, N., New mixed-ligand copper(I) complexes with 2,2'bipyridine and their NMR spectra. Inorganic Chemistry 1982, 21 (10), 3842-3843. 
50. Munakata, M.; Kitagawa, S.; Kosome, S.; Asahara, A., Studies of copper(I) olefin complexes. Formation constants of copper olefin complexes with 2,2'-bipyridine, 1,10phenanthroline, and their derivatives. Inorganic Chemistry 1986, 25 (15), 2622-2627.

51. Thompson, J. S.; Swiatek, R. M., Copper(I) complexes with unsaturated small molecules. Synthesis and properties of monoolefin and carbonyl complexes. Inorganic Chemistry 1985, 24 (1), 110-113.

52. Eckenhoff, W. T.; Pintauer, T., Structural Comparison of Copper(I) and Copper(II) Complexes with Tris(2-pyridylmethyl)amine Ligand. Inorganic Chemistry 2010, 49 (22), 10617 10626.

53. Zerk, T. J.; Bernhardt, P. V., Redox-coupled structural changes in copper chemistry: Implications for atom transfer catalysis. Coordination Chemistry Reviews.

54. Hiskey, M. A.; Ruminski, R. R., Synthesis, spectroscopy, electrochemistry, and photochemistry of a series of $\mathrm{M}($ bpym)2Cl2 (M=Mn(II), $\mathrm{Co}(\mathrm{II}), \mathrm{Ni}(\mathrm{II})$, and $\mathrm{Cu}(\mathrm{II})$ ) complexes. Precursor complexes in the preparation of polymetallic systems. Inorganica Chimica Acta 1986, 112 (2), 189-195.

55. McLachlan, G. A.; Fallon, G. D.; Martin, R. L.; Spiccia, L., Synthesis, Structure and Properties of Five-Coordinate Copper(II) Complexes of Pentadentate Ligands with Pyridyl Pendant Arms. Inorganic Chemistry 1995, 34 (1), 254-261.

56. Pintauer, T.; Qiu, J.; Kickelbick, G.; Matyjaszewski, K., Synthesis, Characterization, and Bromine Substitution by 4,4'-Di(5-nonyl)-2,2'-bipyridine in CuII(4,4'-di(5-nonyl)-2,2'bipyridine)Br2. Inorganic Chemistry 2001, 40 (12), 2818-2824.

57. Bortolamei, N.; Isse, A. A.; Di Marco, V. B.; Gennaro, A.; Matyjaszewski, K., Thermodynamic Properties of Copper Complexes Used as Catalysts in Atom Transfer Radical Polymerization. Macromolecules 2010, 43 (22), 9257-9267.

58. De Paoli, P.; Isse, A. A.; Bortolamei, N.; Gennaro, A., New insights into the mechanism of activation of atom transfer radical polymerization by $\mathrm{Cu}(\mathrm{i})$ complexes. Chemical Communications 2011, 47 (12), 3580-3582.

59. Qiu, J.; Matyjaszewski, K.; Thouin, L.; Amatore, C., Cyclic voltammetric studies of copper complexes catalyzing atom transfer radical polymerization. Macromolecular Chemistry and Physics 2000, 201 (14), 1625-1631.

60. S. Ahrland, K. N., B Tagesson, Thermodynamics of the Copper(I) Halide and Thiocyanate Complex Formation in Acetonitrile. Acta Chemica Scandinavica A 1983, 37, 193-201.

61. Gritzner, G., Solvent effects on half-wave potentials. The Journal of Physical Chemistry 1986, 90 (21), 5478-5485.

62. Ribelli, T. G.; Augustine, K. F.; Fantin, M.; Krys, P.; Poli, R.; Matyjaszewski, K., Disproportionation or Combination? The Termination of Acrylate Radicals in ATRP. Macromolecules 2017, 50 (20), 7920-7929.

63. Fantin, M.; Isse, A. A.; Matyjaszewski, K.; Gennaro, A., ATRP in Water: Kinetic Analysis of Active and Super-Active Catalysts for Enhanced Polymerization Control. Macromolecules 2017, 50 (7), 2696-2705.

64. Bell, C. A.; Bernhardt, P. V.; Monteiro, M. J., A Rapid Electrochemical Method for Determining Rate Coefficients for Copper-Catalyzed Polymerizations. Journal of the American Chemical Society 2011, 133 (31), 11944-11947.

65. Marco Fantin, F. L., Armando Gennaro, Abdirisak A. Isse, Krzysztof Matyjaszewski, Electron Transfer Reactions in Atom Transfer Radical Polymerization. Synthesis 2017, 49 (15), 2211-3322. 
66. Bortolamei, N.; Isse, A. A.; Magenau, A. J. D.; Gennaro, A.; Matyjaszewski, K., Controlled Aqueous Atom Transfer Radical Polymerization with Electrochemical Generation of the Active Catalyst. Angewandte Chemie International Edition 2011, 50 (48), 11391-11394.

67. Fantin, M.; Isse, A. A.; Gennaro, A.; Matyjaszewski, K., Understanding the Fundamentals of Aqueous ATRP and Defining Conditions for Better Control. Macromolecules 2015, 48 (19), 6862-6875.

68. D'Hooge, D. R.; Konkolewicz, D.; Reyniers, M.-F.; Marin, G. B.; Matyjaszewski, K., Kinetic Modeling of ICAR ATRP. Macromolecular Theory and Simulations 2012, 21 (1), 52-69.

69. Ribelli, T. G.; Konkolewicz, D.; Pan, X.; Matyjaszewski, K., Contribution of Photochemistry to Activator Regeneration in ATRP. Macromolecules 2014, 47 (18), 6316-6321.

70. Krys, P.; Matyjaszewski, K., Kinetics of Atom Transfer Radical Polymerization. European Polymer Journal 2017, 89, 482-523.

71. Ribelli, T. G.; Wahidur Rahaman, S. M.; Daran, J.-C.; Krys, P.; Matyjaszewski, K.; Poli, R., Effect of Ligand Structure on the CuII-R OMRP Dormant Species and Its Consequences for Catalytic Radical Termination in ATRP. Macromolecules 2016, 49 (20), 7749-7757.

72. $\quad$ Krys, P.; Ribelli, T. G.; Matyjaszewski, K.; Gennaro, A., Relation between Overall Rate of ATRP and Rates of Activation of Dormant Species. Macromolecules 2016, 49 (7), 2467-2476. 73. Barner-Kowollik, C.; Beuermann, S.; Buback, M.; Castignolles, P.; Charleux, B.; Coote, M. L.; Hutchinson, R. A.; Junkers, T.; Lacik, I.; Russell, G. T.; Stach, M.; van Herk, A. M., Critically evaluated rate coefficients in radical polymerization - 7. Secondary-radical propagation rate coefficients for methyl acrylate in the bulk. Polymer Chemistry 2014, 5 (1), 204-212.

\section{For Table of Contents Use Only}

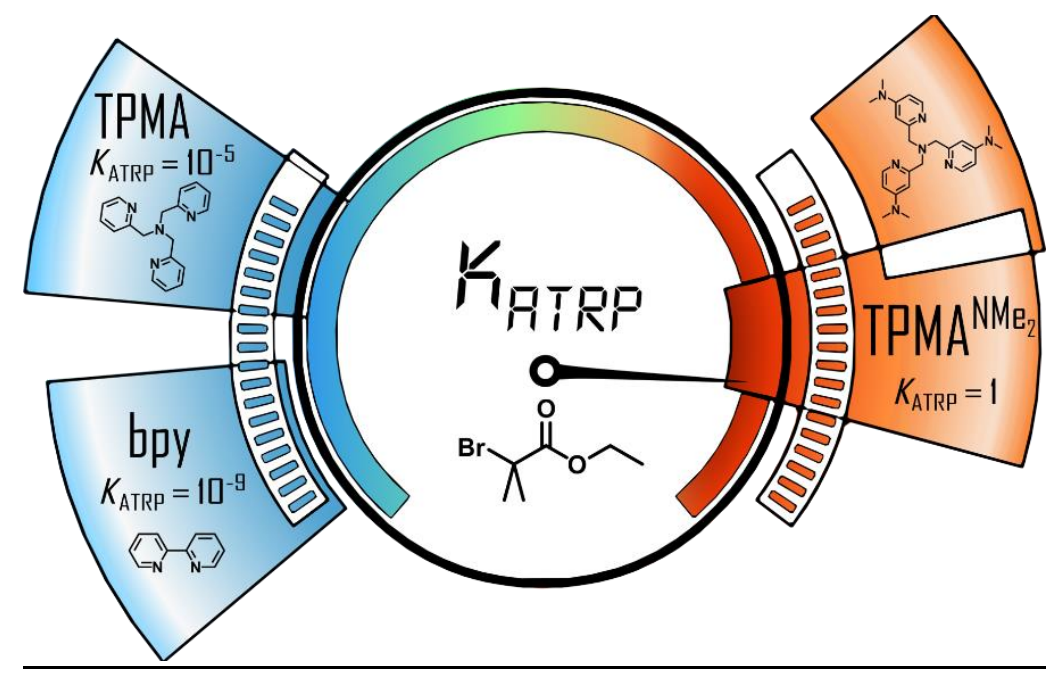

